
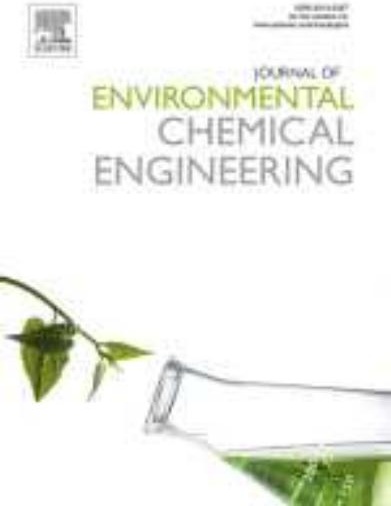


\section{Journal of Environmental Chemical Engineering}

Supports open access

6.7

CiteScore
4.3

Impact Factor $\equiv$ Menu

Q Search in this journal
Submit your article $\nearrow$ Guide for authors $\nearrow$

\section{About the journal}

Aims and scope

\section{Editorial board}

\section{Abstracting and indexing}

\section{Editors}

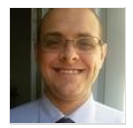

\section{Guilherme Luiz Dotto}

Federal University of Santa Maria, Department of Chemical Engineering, SANTA MARIA, Brazil

Adsorption/biosorption of contaminants from aqueous solutions, preparation and characterization of biomaterials and nanobiomaterials, wastewater treatment, wastes management, and reuse, drying of biomaterials, statistical optimization, experimental design, response surface methodology, linear and non-linear regression analysis

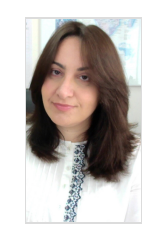

\section{Despo Fatta-Kassinos}

University of Cyprus Department of Civil and Environmental Engineering, Nicosia, Cyprus

Wastewater treatment, advanced oxidation processes, wastewater reuse, antimicrobial resistance, contaminants of emerging concern

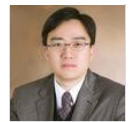

Yunho Lee

Gwangju Institute of Science and Technology, Gwangju, Republic of Korea

Drinking water, disinfection, oxidation, ozone, advanced oxidation process, micropollutants, antibiotic resistance, water reuse

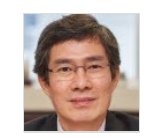

Teik-Thye Lim

Nanyang Technological University, Singapore, Singapore

Advanced Oxidation Processes; Environmental Catalysis; Industrial Wastewater Treatment; Environmental Nanomaterials; Resource Recovery

\section{Associate Editors}




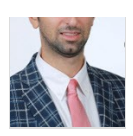

Giovanni Palmisano

Khalifa University of Science \& Technology, Department of Chemical Engineering, Abu Dhabi, United Arab Emirates

Photo(electro)catalysis applied to water treatment, Environmental remediation, $\mathrm{H} 2$ generation, $\mathrm{CO} 2$ reduction and selective oxidation; Self-cleaning surfaces

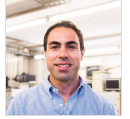

Vítor Vilar

University of Porto, Porto, Portugal

Environmental assessment and monitoring of surface waters, Environmental remediation technologies, Biological oxidation, Coagulation/flocculation, Adsorption/biosorption, Ion-exchange, Advanced oxidation processes, Electrochemical advanced oxidation processes, Ozonation, Membrane filtration, Wastewater resources recovery, Process integration \& intensification, ,

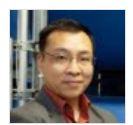

Wen Zhang

New Jersey Institute of Technology, Department of Civil and Environmental Engineering, Newark, New Jersey, United States

Colloidal interfaces, nanomaterial characterization, environmental nanotechnology, reactive membranes

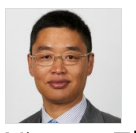

Xiwang Zhang

Monash University Department of Chemical Engineering, Clayton, Victoria, Australia

Membrane Synthesis, Membrane Process; 2D materials, Nanoporous Materials; Catalytic Oxidation and Resource Recovery.

\section{Editorial Board Members}

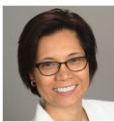

\section{Diana Aga}

University at Buffalo Department of Chemistry, Buffalo, New York, United States

Environmental Analysis, Emerging Contaminants, Persistent Organic Pollutants, Wastewater Treatment, Biodegradation, Antibiotic Resistance, Mass Spectrometry, Ecotoxicity

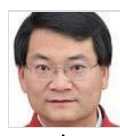

Taicheng An

Guangdong University of Technology - University Town Campus, Institute of Environmental Health and Pollution Control, Guangzhou, China Fate and transport of micropollutants; Disinfection; Photocatalysis (heterogeneous); Air pollution control; Photocatalysis (air treatment

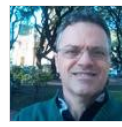

Antonio Reinaldo Cestari

Federal University of Sergipe, Brazil

\section{Sara J. Couperthwaite}

Queensland University of Technology Faculty of Science and Engineering, Brisbane, Australia 


\section{8}

A.J. Andrew J. Daugulis

Queen's University Department of Chemistry, Kingston, Ontario, Canada

Environmental Biotechnology, Bioresource Engineering, Cell Culture Engineering, and Industrial Bioprocesssing

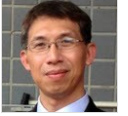

Ruey-an Doong

National Tsing Hua University, Institute of Analytical and Environmental Sciences, Hsinchu, Taiwan

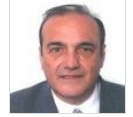

Santi Esplugas

University of Barcelona, Barcelona, Spain

Advanced Oxidation Processes, Photocatalysis, Fenton, Ozonation, Wastewater treatment

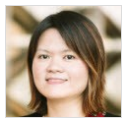

Peiying Hong

King Abdullah University of Science and Technology, Division of Biological and Environmental Science and Engineering, Thuwal, Saudi Arabia Microbial contaminants, water quality, water reuse, wastewater, anaerobic biotechnologies

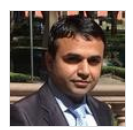

Hafiz M. N. Iqbal

Technological and Higher Education Institute of Monterrey, School of Engineering and Sciences, Monterrey, Mexico

Environmental Engineering, Bioengineering, Biomedical Engineering, Bioremediation, Emerging contaminants, Wastewater treatment, Biomaterials, Bio-catalysis, Enzymes, Enzyme-based pollutant degradation, Immobilization, Toxic heavy elements, Liquid and solid waste management, Valorization of agro-industrial wastes and by-products

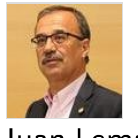

Juan Lema

University of Santiago de Compostela, CRETUS Institute, Santiago de Compostela, Spain

Novel wastewater treatment processes; Anaerobic (co) Digestion; Removal of contaminants of emerging concern from wastewater and sludge;

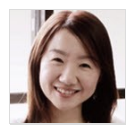

\section{Angela Yu-Chen Lin}

National Taiwan University Graduate Institute of Environmental Engineering, Taipei, Taiwan

Emerging contaminants, Environmental photochemistry, Environmental chemistry and analysis, Transformation and risk of organic micropollutants, Water/wastewater treatment technology and reuse

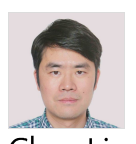

Chao Liu

Clemson University, Department of Environmental Engineering and Earth Sciences, Anderson, South Carolina, United States

Drinking water quality, disinfection/oxidation, disinfection byproducts, contaminants of emerging concern, advanced water treatment 


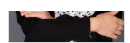

Célia Manaia

Catholic University of Portugal Faculty of Biotechnology, Porto, Portugal

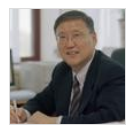

In-Sik Nam

Pohang University of Science and Technology, Department of Chemical Engineering, Pohang, Korea, Republic of

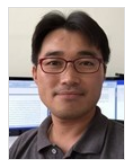

Hyunwoong Park

Kyungpook National University, School of Energy Engineering, Daegu, South Korea

Roberto Parra Saldívar

Monterrey Institute of Technology and Higher Education, Monterrey, Mexico

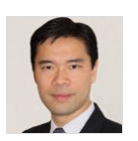

Kaimin Shih

University of Hong Kong Department of Civil Engineering, Hong Kong, Hong Kong

Environmental Materials, Waste Engineering, Energy Materials, Waste-to-Resource, Wastewater Treatment

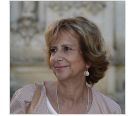

Maria Concetta Tomei

Water Research Institute National Research Council, Roma, Italy

Processes and Technologies for Urban and Industrial Wastewater Treatment, Modelling and Control of Biological Processes, Removal of Xenobiotic Compounds, Membrane bioreactors, Sludge Treatment, Soil Bioremediation

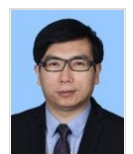

Zhiwei Wang

Tongji University School of Environmental Science and Engineering, Shanghai, China

Wastewater treatment; Water reclamation; Membrane technology; Activated sludge treatment process; Resource recovery

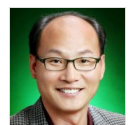

Yeoung-Sang Yun

Jeonbuk National University, School of Chemical Engineering, Jeonju, Korea, Republic of

Biosorbents and biosorption; Fate and degradation of emerging contaminants; Bio-inspired synthesis of nanomaterials; Boosting the natural purification process

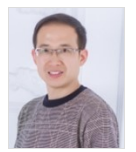

Huabao Zheng

Zhejiang A and F University, Department of Environmental Science and Engineering, Hangzhou, China

\section{Early Career Editorial Board}




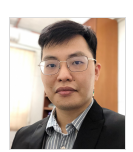

Oh Wen Da

Universiti Sains Malaysia, Pulau Pinang, Malaysia

Environmental catalysis, Advanced Oxidation Processes, Waste-to-Resources, Adsorption, Photocatalysis

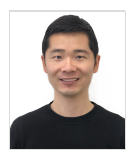

Xiaoguang Duan

The University of Adelaide, Adelaide, Australia

Advanced Oxidation Processes, functional materials, nanocarbons, green catalysis, environmental nanotechnology

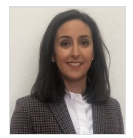

Patricia Garcia-Munoz

Polytechnic University of Madrid, Madrid, Spain

Advanced oxidation processes, Wastewater treatment, Photocatalysis, Fenton-related processes, Photocatalytic materials

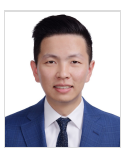

Yuxiong Huang

Tsinghua-Berkeley Shenzhen Institute, Shenzhen, China

Environmental Nanotechnology, Water Treatment, Environmental Analytical Chemistry, Emerging Contaminants, Surface and Interfacial Engineering

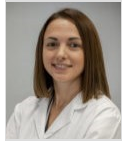

Popi Karaolia

University of Cyprus, Lefkosia, Cyprus

Antibiotic resistance, Advanced Oxidation Processes, Wastewater treatment, Membrane Bioreactor, Disinfection

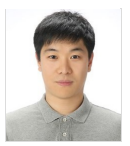

\section{Choonsoo Kim}

Kongju National University, Gongju, Korea, Republic of

Electrochemical Water treatment, Electrochemical Advanced Oxidation Process (EAOP), Electrochemical Ion Separation (EIONS), Capacitive Deionization (CDI), Resource Recovery

\section{n}

Francisca Moreira

University of Porto, Porto, Portugal

Wastewater treatment, Process integration and intensification, Organic synthesis, Wastewater resources recovery, Electrochemical advanced oxidation processes 
Photocatalysis, Ozonation, Plasma, Process Intensification, Advanced Oxidation Processes, Green Chemistry, Photocatalytic Syntheses, Kinetic Modelling, Photoactive Materials, Environmental Chemistry

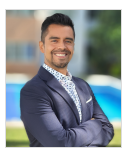

Hugo Olvera Vargas

National Autonomous University of Mexico, Mexico City, Mexico

Environmental electrochemistry, Electrochemical advanced oxidation processes, Wastewater treatment and resource recovery, Photoelectrocatalysis, Environmental analysis and emerging contaminants

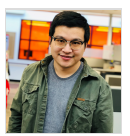

Dawei Wang

Hohai University, Nanjing, China

Nanomaterials, Photocatalysis, Advanced Oxidation Process, Emerging Contaminants, Wastewater

All members of the Editorial Board have identified their affiliated institutions or organizations, along with the corresponding country or geographic region. Elsevier remains neutral with regard to any jurisdictional claims.

ISSN: 2213-3437

Copyright (C) 2021 Elsevier Ltd. All rights reserved 


\section{Journal of Environmental Chemical Engineering}

Supports open access

\section{Volume 9 , Issue 2}

In progress (April 2021)

This issue is in progress but contains articles that are final and fully citable.

Receive an update when the latest issues in this journal are published

Sign in to set up alerts

\section{Research Articles}

Research article $\bigcirc$ Abstract only

Simbang Darah (Iresine herbstii) extract mediated hydrothermal method in the synthesis of zinc ferrite spinel nanoparticles used for photocatalysis and antibacterial applications

Rahmayeni, Rike Febrialita, Yeni Stiadi, Yulia Eka Putri, ... Zulhadjri

Article 105140

$\Downarrow$ Purchase PDF Article preview $\vee$

Research article $\bigcirc$ Abstract only

Statistical optimization of levulinic acid and formic acid production from lipid-extracted residue of Chlorella vulgaris

Gwi-Taek Jeong, Sung-Koo Kim

Article 105142

$\Perp$ Purchase PDF Article preview $\vee$

Research article $\bigcirc$ Abstract only

$\mathrm{NiMn}_{2} \mathrm{O}_{4}$ sphere catalyst for the selective catalytic reduction of $\mathrm{NO}$ by $\mathrm{NH}_{3}$ : Insight into the enhanced activity via solvothermal method

Jiangning Liu, Xu Wu, Benhui Hou, Yali Du, ... Baoshuan Yang

Article 105152 


\section{Journal of Environmental Chemical Engineering}

Supports open access

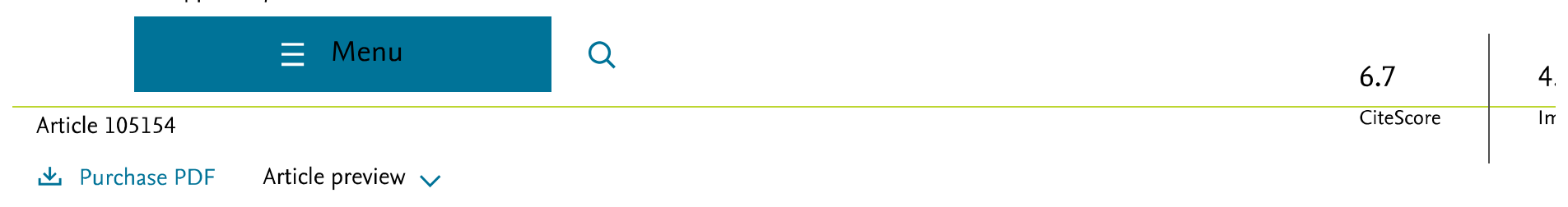

Research article $\bigcirc$ Abstract only

On the hydrothermal-enhanced synthesis of highly selective $\mathrm{Mo}_{2} \mathrm{C}$ catalysts to fully deoxygenated products in the guaiacol

HDO reaction

E. Ochoa, D. Torres, J.L. Pinilla, I. Suelves

Article 105146

$\Perp$ Purchase PDF Article preview $\vee$

Research article $\bigcirc$ Abstract only

Removal of benzophenone aerosols by a rice straw-based activated carbon filter combined with a negative air ionizer Ming-Hsuan Tsai, Abiyu Kerebo Berekute, Yu Wei Tsai, Kun-Yi Lin, Kuo-Pin Yu

Article 105141

$\Perp$ Purchase PDF Article preview $\vee$

Research article $\bigcirc$ Abstract only

Preparation and characterization of magnetic photocatalyst from the banded iron formation for effective photodegradation of methylene blue under UV and visible illumination

Moustafa M.S. Sanad, Mohsen M. Farahat, Soliman I. El-Hout, Said M. El-Sheikh

Article 105127

$\Perp$ Purchase PDF Article preview $\vee$

Research article $\bigcirc$ Abstract only

$\mathrm{CO}_{2}$ adsorption investigation by statistical physics: Thermodynamic analysis for cooling cycle application

Wouroud Sghaier, Yosra Ben Torkia, Mohamed Bouzid, Abdelmottaleb Ben Lamine

Article 105108

$\Downarrow$ Purchase PDF Article preview $\vee$

Research article $\bigcirc$ Abstract only

Activated carbon from macauba endocarp (Acrocomia aculeate) for removal of atrazine: Experimental and theoretical investigation using descriptors based on DFT

Wedja Timóteo Vieira, Mozart Daltro Bispo, Samara de Melo Farias, Arthur da Silva Vasconcelos de Almeida, ... Tatiane Luciano Balliano

Article 105155

$\Downarrow$ Purchase PDF Article preview $\vee$

Research article $\bigcirc$ Abstract only

Engineering of oxygen vacancy as defect sites in silicates for removal of diverse organic pollutants and enhanced aromatic alcohol oxidation

Debashrita Sarkar, Khushboo S. Paliwal, Sagar Ganguli, Athma E. Praveen, ... Venkataramanan Mahalingam

Article 105134

$\downarrow$ Purchase PDF Article preview $\vee$ 


\section{Journal of Environmental Chemical Engineering}

Supports open access

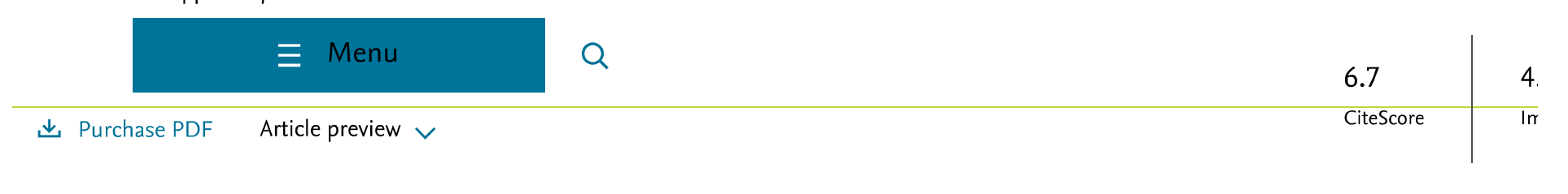

Research article $\bigcirc$ Abstract only

Environmentally friendly magnetic chitosan nano-biocomposite for $\mathrm{Cu}$ (II) ions adsorption and magnetic nano-fluid

hyperthermia: CCD-RSM design

Elham Cheraghipour, Mahmoud Pakshir

Article 104883

$\Downarrow$ Purchase PDF Article preview $\vee$

Research article $\bigcirc$ Abstract only

Peroxydisulfate activation process on copper oxide: $\mathrm{Cu}(\mathrm{III})$ as the predominant selective intermediate oxidant for phenol and waterborne antibiotics removal

Chan Li, Vincent Goetz, Serge Chiron

Article 105145

出 Purchase PDF Article preview $\vee$

\section{Short Communications}

\section{Short communication $\bigcirc$ Abstract only}

The presence of low fouling-causing bacteria can lead to decreased membrane fouling potentials of mixed cultures

Naga Raju Maddela, Ronald Oswaldo Villamar Torres

Article 105131

$\Perp$ Purchase PDF Article preview $\vee$

Special Issue on Advanced Oxidation Processes for Water and Wastewater Treatment

Research article $\bigcirc$ Abstract only

Cytotoxic effects of silver nanoparticles on Ruellia tuberosa: Photocatalytic degradation properties against crystal violet and coomassie brilliant blue

Vasantharaj Seerangaraj, Selvam Sathiyavimal, Sripriya Nannu Shankar, Jaya Ganesh Thiruvengadam Nandagopal, ... Arivalagan Pugazhendhi

Article 105088

$\downarrow$ Purchase PDF Article preview $\vee$

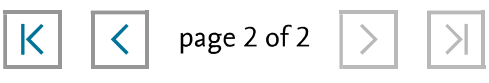


Journal of Environmental Chemical Engineering | Vol 9, Issue 2, In progr... https://www.sciencedirect.com/journal/journal-of-environmental-chemica...

\section{Journal of Environmental Chemical Engineering \\ Supports open access}

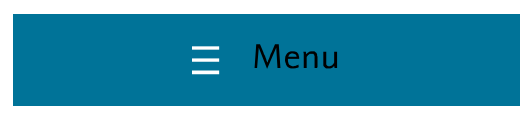

Q

6.7

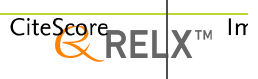

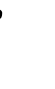

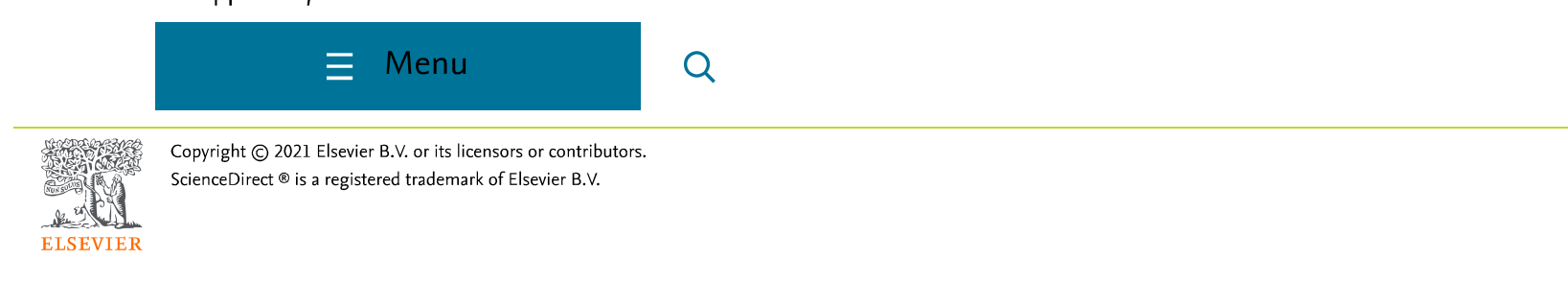




\title{
Simbang Darah (Iresine herbstii) extract mediated hydrothermal method in the synthesis of zinc ferrite spinel nanoparticles used for photocatalysis and antibacterial applications
}

\author{
Rahmayeni $^{\text {a, }}{ }^{*}$, Rike Febrialita ${ }^{a}$, Yeni Stiadi ${ }^{a}$, Yulia Eka Putri ${ }^{a}$, Nofrijon Sofyan ${ }^{b}$, Zulhadjri $^{\text {a }}$ \\ ${ }^{a}$ Department of Chemistry, Faculty of Mathematics and Natural Sciences, Universitas Andalas, Kampus Limau Manis, Padang 25163, Indonesia \\ ${ }^{\mathrm{b}}$ Department of Metallurgical and Materials Engineering, Faculty of Engineering, Universitas Indonesia, Kampus Baru UI-Depok, 16424, Indonesia
}

\section{A R T I C L E I N F O}

Editor: Dr. G.L. Dotto

\section{Keywords:}

$\mathrm{ZnFe}_{2} \mathrm{O}_{4}$ nanoparticles

Hydrothermal

Iresine herbstii

Direct red 81

Antibacterial

\begin{abstract}
A B S T R A C T
This paper reports the use of Simbang Darah (Iresine herbstii) leaf extract to synthesize $\mathrm{ZnFe}_{2} \mathrm{O}_{4}$ spinel ferrite nanoparticles via hydrothermal method. Biochemical compounds in Simbang Darah leaf extract act as a capping agent and a stabilizer to form nanostructures. XRD patterns and FTIR spectrums confirm the formation of the cubic spinel crystal structure of $\mathrm{ZnFe}_{2} \mathrm{O}_{4}$ nanoparticles. SEM and TEM characterization revealed that $\mathrm{ZnFe}_{2} \mathrm{O}_{4}$ spinel ferrite morphology has a uniform spherical shape in nanoscale. EDX results showed that the compositional mass ratios were relevant as expected from the synthesis. $\mathrm{ZnFe}_{2} \mathrm{O}_{4}$ nanoparticles have an absorption edge in the visible region with Eg values within the range 2.05-2.11 eV in the DRS UV-Vis analysis. The as-prepared samples exhibit paramagnetic behavior according to the magnetic hysteresis curve. $\mathrm{ZnFe}_{2} \mathrm{O}_{4}$ nanoparticles were proven effective in direct red 81 dye photodegradation (99.66\%) after exposure to solar light irradiation for two hours. On top of that, $\mathrm{ZnFe}_{2} \mathrm{O}_{4}$ nanoparticle exhibited antibacterial activity against $S$. aureus and E. coli.
\end{abstract}

\section{Introduction}

Zinc ferrite $\left(\mathrm{ZnFe}_{2} \mathrm{O}_{4}\right)$ is an important magnetic material that has attracted significant interest due to its unique optical, magnetic, and electrical properties. It has a normal spinel phase where $\mathrm{Zn}^{2+}$ ions occupy the tetrahedral site, and $\mathrm{Fe}^{3+}$ ions occupy the octahedral site. In nanoscale, the changes of $\mathrm{ZnFe}_{2} \mathrm{O}_{4}$ structure into mixed spinel can increase its magnetic properties to become superparamagnetic [1,2]. Zinc ferrite has been widely used in many fields such as biomedicine [3], the production of battery anodes [4], gas sensors [5,6], planar drug delivery [7], besides acting as antibacterial agent [8], photocatalysts, and absorbent material $[9,10]$. It can be manufactured via various techniques such as co-precipitation route [11], one step and multistep hydrothermal method [12,13], solvothermal method [10], combustion route [14], solution combustion reaction [6], thermal method using reducing and capping agents [15], and soft chemical route [16]. Each method has its advantages and disadvantages such as simplicity, convenience, temperature, and hazardous chemicals usage.

Many researchers are currently focused on using natural substances derived from plants or microorganism to synthesize functional materials. This approach can replace hazardous chemicals and offer an environmentally friendly synthesis [17]. In addition, the utilization of several plant extracts as stabilizers in the biosynthesis of ferrite material with nanostructures has been proven to be environmentally friendly, easy to obtain, low-cost, and non-toxic [18].

In recent years, there have been many reports of the green synthesis of $\mathrm{ZnFe}_{2} \mathrm{O}_{4}$ compound by different methods. For instance, Kombaiah et al. [19] synthesized $\mathrm{ZnFe}_{2} \mathrm{O}_{4}$ using Hibiscus rosa-sinensis extract as a reducing and stabilizer agent via conventional and microwave combustion methods. Meanwhile, Patil et al. [14] used sugarcane juice as fuel in $\mathrm{ZnFe}_{2} \mathrm{O}_{4}$ synthesis via combustion method. Additionally, Matinise et al. [20] utilized Moringa oleifera extract as chelating and reducing agents in the synthesis of $\mathrm{ZnFe}_{2} \mathrm{O}_{4}$. Furthermore, Limonia aciddissima juice was used as fuel in the synthesis of $\mathrm{ZnFe}_{2} \mathrm{O}_{4}$ using microwave by Madhukara Naik et al. [21]. Moreover, Sriramulu et al. [17] used Aegle marmelos leaves extract in the synthesis of $\mathrm{ZnFe}_{2} \mathrm{O}_{4}$. The biosynthesis of zinc ferrite produced small particles with a homogeneous, smooth, and stable structure [18].

Simbang Darah (Iresine herbstii) is a family of Amaranthaceae with various leaf colors ranging from purple or dark purple to green (Fig. 1). Its leaves have been used as a traditional remedy for eczema and acne scars for humans. Besides, Simbang Darah leaves are boiled in water and

\footnotetext{
* Corresponding author.

E-mail address: rahmayenni@sci.unand.ac.id (Rahmayeni).
} 


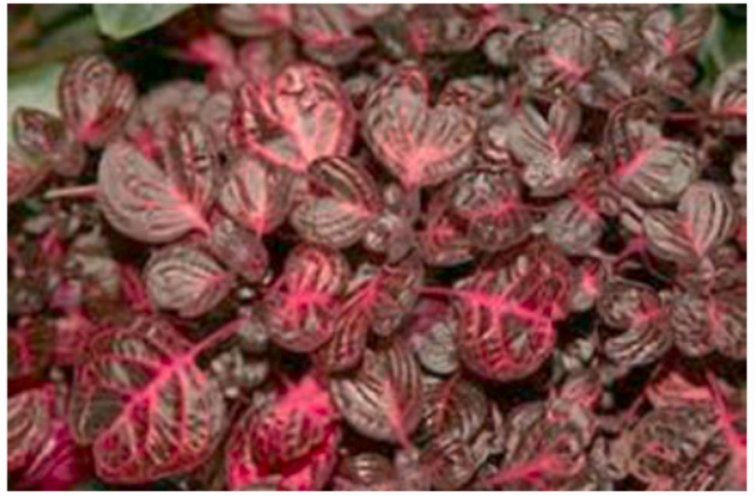

Fig. 1. Simbang Darah (Iresine herbstii) leaves.

used as an antipyretic and tonic to treat anemia. In the biomedical field, Simbang Darah has been used as an anti-cancer and antimicrobial agent $[22,23]$. Simbang Darah contains several compounds including $3^{\prime}, 4^{\prime}$, 7-trihydroxy-6-methoxy flavone, N-feruloyltyramine, glycinebetaine and trigonelline, betacyanin acylate-amaranthine, isoamaranthine, iresin I, isoiresin I (= iresin II), iresinin III and iresinin IV [24]. In the latest research, this plant was found to contain isoflavone compounds $2^{\prime}, 2$, 5-trimethoxy-6,7-methylenedioxysiisoflavone and tlatlancuayin isoflavones (2', 5-dimethoxy-6,7-methylenedioxyisoflavone) [25]. Several advantages of using Simbang Darah leaves include easy to obtain, easy to extract, and economical. As of today, there have been no reports of $\mathrm{ZnFe}_{2} \mathrm{O}_{4}$ hydrothermal synthesis using Simbang Darah leaf extract.

In this study, a green synthesis approach was used to synthesize $\mathrm{ZnFe}_{2} \mathrm{O}_{4}$ magnetic material via the hydrothermal method using Simbang Darah extract as a capping and a stabilizer agent. The obtained $\mathrm{ZnFe}_{2} \mathrm{O}_{4}$ nanoparticles were characterized using several instruments to analyze the crystal structure and crystallite size, morphology, magnetic properties, optical properties, binding energy, and interatomic interactions in their spinel structures. The photocatalytic activity of $\mathrm{ZnFe}_{2} \mathrm{O}_{4}$ was evaluated on the degradation of direct red 81 dyes under natural sunlight. Direct red 81 with molecular formula $\mathrm{C}_{29} \mathrm{H}_{19} \mathrm{~N}_{5} \mathrm{Na}_{2} \mathrm{O}_{8} \mathrm{~S}_{2}$ is one of the synthetic dyes in the textile industry and has been known for its carcinogenic nature and toxicity towards animals and humans [26,27]. Furthermore, the antibacterial activity of $\mathrm{ZnFe}_{2} \mathrm{O}_{4}$ was also tested against pathogenic bacteria found in wastewater, i.e., S. aureus and E. coli.

\section{Materials and methods}

\subsection{Materials}

$\mathrm{Zn}\left(\mathrm{NO}_{3}\right)_{2} \cdot 4 \mathrm{H}_{2} \mathrm{O}$ (Sigma-Aldrich) and $\mathrm{Fe}\left(\mathrm{NO}_{3}\right) \cdot 9 \mathrm{H}_{2} \mathrm{O}$ (Sigma-Aldrich) were used as precursors without further treatment. $\mathrm{NaOH}$ (Merck) was used as a mineralizer, with Nutrient agar, and distilled water. Direct red 81 dye was obtained from the local textile factory. Meanwhile, Simbang Darah (Iresine herbstii) leaves were obtained from Alahan Panjang, West Sumatra, Indonesia. The pathogenic bacteria were obtained from the Microbiology Laboratory, Faculty of Agriculture, Universitas Andalas. All solutions were prepared using deionized water.

\subsection{Extract preparation}

Simbang Darah leaves (Fig. 1.) were separated from the stems, washed with distilled water, and dried in a closed room $\left(25-28{ }^{\circ} \mathrm{C}\right)$ for ten days. Then, the dried leaves were blended into fine powder form. A total of $5 \mathrm{~g}$ of Simbang Darah leaf powder was added to $100 \mathrm{~mL}$ of distilled water and heated for $2 \mathrm{~h}$ at $58{ }^{\circ} \mathrm{C}$ under agitation at $300 \mathrm{rpm}$. After that, the extract was filtered and stored in a refrigerator momentarily before synthesizing zinc ferrite nanoparticles.

\subsection{Synthesis of $\mathrm{ZnFe}_{2} \mathrm{O}_{4}$ nanoparticles}

The $\mathrm{ZnFe}_{2} \mathrm{O}_{4}$ nanoparticles were synthesized via the hydrothermal method [28] using Simbang Darah leaf extract as a capping agent. A total of $1.49 \mathrm{~g} \mathrm{Zn}\left(\mathrm{NO}_{3}\right)_{2} .4 \mathrm{H}_{2} \mathrm{O}$ and $4.04 \mathrm{~g} \mathrm{Fe}\left(\mathrm{NO}_{3}\right)_{3} .9 \mathrm{H}_{2} \mathrm{O}$ were mixed in $50 \mathrm{~mL}$ Simbang Darah extract solution. The concentration of Simbang Darah solution was varied by adding 1,3 , and $5 \mathrm{~mL}$ of concentrated extract in $50 \mathrm{~mL}$ of solution. The mixture was stirred at $500 \mathrm{rpm}$ for $1 \mathrm{~h}$ before adding $4 \mathrm{M}$ sodium hydroxide $(\mathrm{NaOH})$ to the mixture until $\mathrm{pH}$ of 12 was achieved. The stirring was continued for another $2 \mathrm{~h}$. Later, the suspension was poured into an autoclave tube and heated at $180{ }^{\circ} \mathrm{C}$ for $3 \mathrm{~h}$. The resulted precipitation was filtered, washed several times using distilled water until the $\mathrm{pH} 7$ was achieved, and then heated in an oven at $110{ }^{\circ} \mathrm{C}$ for $4 \mathrm{~h}$. The obtained $\mathrm{ZnFe}_{2} \mathrm{O}_{4}$ powders were labeled as $\mathrm{ZnE}_{1} \mathrm{~N}$, $\mathrm{ZnE}_{3} \mathrm{~N}$, and $\mathrm{ZnE}_{5} \mathrm{~N}$, respectively. In order to investigate the effect of temperature on the structure formation of ferrite, the samples were calcined at $500{ }^{\circ} \mathrm{C}$ for $2 \mathrm{~h}$. After that, the calcined ferrite powders were labeled as $\mathrm{ZnE}_{1} \mathrm{NK}, \mathrm{ZnE}_{3} \mathrm{NK}$, and $\mathrm{ZnE}_{5} \mathrm{NK}$ for 1,3 , and $5 \mathrm{~mL}$ extracts, respectively.

\subsection{Material characterization}

The phase composition and crystalline structure of zinc ferrite nanocrystals were studied using X-ray diffraction (PANalytical X'pert Pro Multipurpose Diffractometer) with $\mathrm{Cu}-\mathrm{K} \alpha$ radiation $(\lambda=1.5406 \AA)$ at $2 \theta$ ranging from $10^{\circ}$ to $90^{\circ}$. The structural parameters were refined using the Le Bail method available in RIETICA software [29]. Then, the average crystallite size was calculated using the standard Scherer formula [18]. Surface morphology and chemical composition of ferrite were examined using a scanning electron microscope (SEM, JEOL JSM-6360LA) embedded with energy-dispersive X-ray spectroscopy (EDS). Detailed morphology of the samples was investigated using a transmission electron microscope (TEM, JEM-1400). High-resolution transmission electron microscopy (FEI, Technai G2, F30) was employed to probe the microstructure, particle size distribution, and high-resolution imaging of zinc ferrite. The binding energy of zinc ferrite was determined by X-ray photoelectron spectroscopy (XPS ULVAC-PHI Quantera SXM). The UV-Vis spectrophotometer analyzed the photoabsorption measurement of ferrites (Shimadzu UV-Vis 2450). The samples' magnetic properties were investigated using a vibrating sample magnetometer (VSM OXFORD 1.2H). FTIR spectra were recorded using a Nicolet IR200FT-IR spectrometer using $\mathrm{KBr}$ pellet technique. The adsorption-desorption isotherms were conducted using a surface area and pore size analyzer (BET, Quantachrome Nova 2000 E).

\subsection{Determination of zinc ferrite photocatalytic activity}

The photocatalytic activity of the synthesized $\mathrm{ZnFe}_{2} \mathrm{O}_{4}$ nanoparticles was determined under solar light irradiation for direct red 81 dye adapted from [28]. $\mathrm{ZnFe}_{2} \mathrm{O}_{4}$ catalyst in powder form was added to a petri dish containing $20 \mathrm{~mL}$ of $35 \mathrm{mg} \mathrm{L}^{-1}$ direct red 81 solutions $(\mathrm{pH}=$ 6) and stored in a dark box for $30 \mathrm{~min}$ to investigate the adsorption process. The mixtures were then exposed for $2 \mathrm{~h}$ under natural solar light irradiation. Furthermore, the liquid was separated from the catalyst, and supernatant absorption was measured at a wavelength of $530 \mathrm{~nm}$ using a UV-visible spectrophotometer. The degradation percentage was calculated with $\% \mathrm{Deg} .=\left(A_{0}-A_{t}\right) / A_{0} \times 100 \%$ using the absorbance of direct red 81, where $A_{0}$ and $A_{t}$ are the initial absorbance and the absorbance at time $t$, respectively. Moreover, the same experiments were performed with the $\mathrm{ZnE}_{1} \mathrm{~N}, \mathrm{ZnE}_{3} \mathrm{~N}, \mathrm{ZnE}_{5} \mathrm{~N}, \mathrm{ZnE} \mathrm{E}_{1} \mathrm{NK}$, $\mathrm{ZnE}_{3} \mathrm{NK}$, and $\mathrm{ZnE}_{5} \mathrm{NK}$ samples. Two samples with the best activity were further tested for several parameters related to photocatalytic activity, i. e., radiation duration $(0.5,1,1.5$, and $2 \mathrm{~h})$ and dye concentration (25, $30,35,40$, and $45 \mathrm{mg} \mathrm{L}^{-1}$ ). The samples were retested in the same manner to investigate their durability and stability against repeated use. Prior to retesting, the used samples were rinsed with distilled water and 


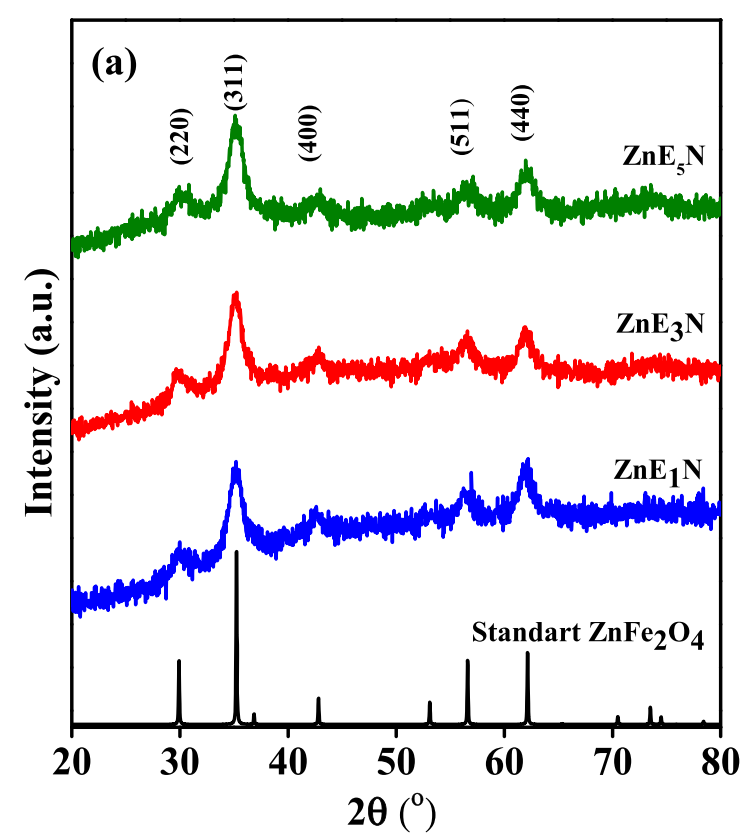

Fig. 2. XRD patterns of $\mathrm{ZnFe}_{2} \mathrm{O}_{4}$ before (a) and after calcination (b) at $500{ }^{\circ}$

later heated in an oven at $110{ }^{\circ} \mathrm{C}$ for $2 \mathrm{~h}$ for activation.

\subsection{Determination of zinc ferrite antibacterial activity}

The antibacterial activities of the samples were screened using two pathogenic bacteria, $S$. aureus and $E$. coli, according to [30,31]. Nutrient agar (NA) was used as a growth media to observe nanoparticles' bactericidal activity in-vitro. Firstly, NA was autoclaved at $120^{\circ} \mathrm{C}$ for $20 \mathrm{~min}$ and then cooled to $45^{\circ} \mathrm{C}$. Petri dishes for the antibacterial assay were also sterilized in an autoclave. Meanwhile, the bacteria were subcultured in $5 \mathrm{~mL}$ of sterile distilled water overnight. A total of $0.1 \mathrm{~mL}$ of the bacterial suspension was added to $20 \mathrm{~mL}$ of NA media and homogenized. Then, the NA media containing the bacteria was poured into a sterile petri dish and allowed to solidify. The $\mathrm{ZnFe}_{2} \mathrm{O}_{4}$ samples were inserted into the wells that had been prepared in the NA media. Amoxicillin was used as a positive control and water as a negative control in this experiment. The inhibition zones of the samples were measured after incubation at $37^{\circ} \mathrm{C}$ for $24 \mathrm{~h}$.

\section{Results and discussion}

\subsection{XRD powder analysis}

The XRD patterns of the $\mathrm{ZnFe}_{2} \mathrm{O}_{4}$ samples synthesized via the hydrothermal method in the presence of Simbang Darah leaf extract before and after calcination are shown in Fig. 2. XRD patterns of $\mathrm{ZnE}_{1} \mathrm{~N}, \mathrm{ZnE}_{3} \mathrm{~N}$, and $\mathrm{ZnE}_{5} \mathrm{~N}$ are shown in Fig. 2a. All XRD peaks have been identified and confirmed to be single-phase $\mathrm{ZnFe}_{2} \mathrm{O}_{4}$ indexed to $\mathrm{Fd} 3 m$ cubic crystal structure (ICSD-158837). The crystallite sizes calculated using the Debye-Scherer's formula are 7.2, 6.8, and $6.0 \mathrm{~nm}$ for $\mathrm{ZnE}_{1} \mathrm{~N}, \mathrm{ZnE}_{3} \mathrm{~N}$, and $\mathrm{ZnE}_{5} \mathrm{~N}$, respectively. The decrease in crystallite size can also be observed visually through the broadening of the diffraction peaks.

Similarly, XRD analysis was also carried out on calcined $\mathrm{ZnE}_{1} \mathrm{NK}$, $\mathrm{ZnE}_{3} \mathrm{NK}$, and $\mathrm{ZnE}_{5} \mathrm{NK}$ samples, as shown in Fig. 2b. The XRD patterns were similar to that of Fig. 2a, but with sharper and well-resolved peaks. The crystallite sizes of the $\mathrm{ZnE}_{1} \mathrm{NK}, \mathrm{ZnE}_{3} \mathrm{NK}$, and $\mathrm{ZnE}_{5} \mathrm{NK}$ samples increase with the calcination process recording $15.8,16.9$, and $14.4 \mathrm{~nm}$, respectively. These results indicated that the calcination accelerates the crystal's grain growth due to the coalescing of many crystallites of the same orientation, forming a large grain with a particular orientation

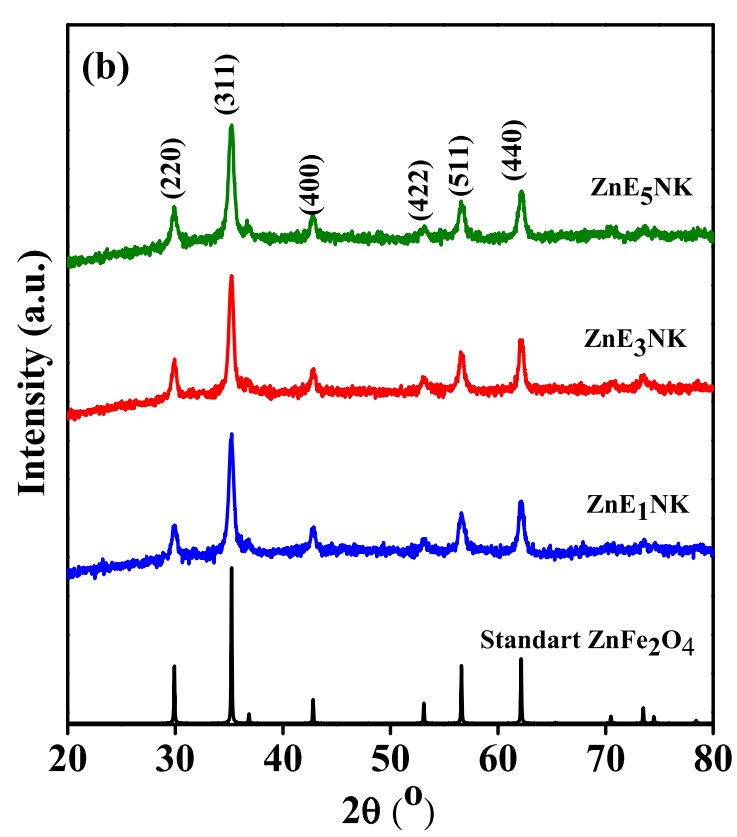

${ }^{\circ} \mathrm{C}$ prepared using Simbang Darah leaf extracts at various concentrations.

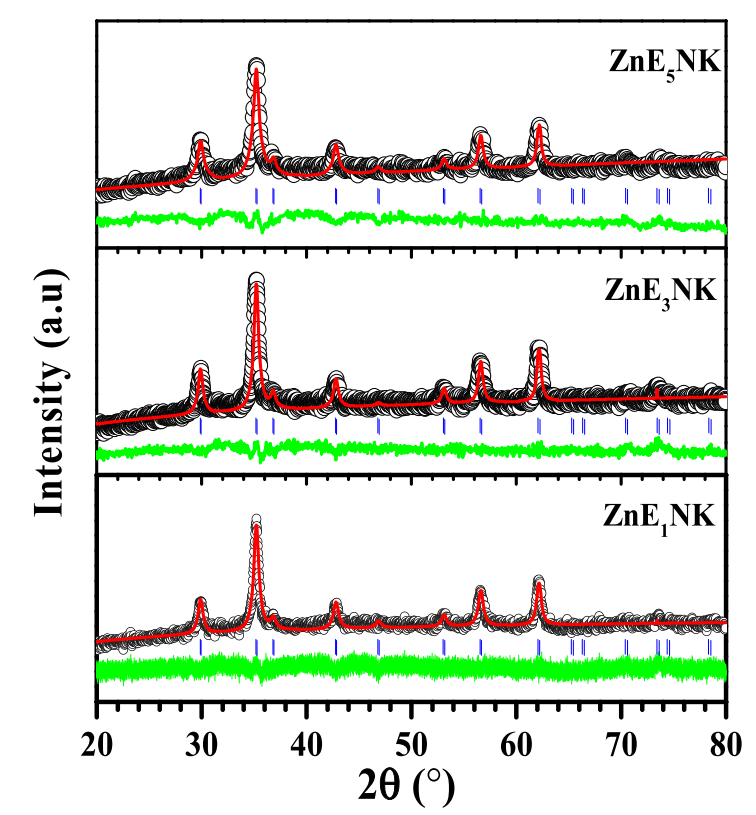

Fig. 3. Rietveld refinement patterns of $\mathrm{ZnFe}_{2} \mathrm{O}_{4}$ after calcination at $500{ }^{\circ} \mathrm{C}$.

[32]. Both XRD pattern and crystallite size of the samples suggested that the Simbang Darah leaf extracts at varying concentrations influenced the formation of $\mathrm{ZnFe}_{2} \mathrm{O}_{4}$ ferrite material with spinel structure. The

Table 1

Refined structural parameters of single-phase $\mathrm{ZnFe}_{2} \mathrm{O}_{4}$ samples after calcination.

\begin{tabular}{llll}
\hline Parameter & $\mathbf{Z n E}_{\mathbf{1}} \mathbf{N K}$ & $\mathbf{Z n E}_{3} \mathbf{N K}$ & $\mathbf{Z n E}_{5} \mathbf{N K}$ \\
\hline Space group & $F d 3 m s$ & $F d 3 m s$ & $F d 3 m s$ \\
Crystal class & Cubic & Cubic & Cubic \\
$a=b=c(\AA)$ & 8.4499 & 8.4487 & 8.4458 \\
$V\left(\AA^{3}\right)$ & 603.33 & 603.07 & 602.45 \\
$Z$ & 8 & 8 & 8 \\
$\mathrm{R}_{p}(\%)$ & 2.12 & 2.65 & 2.16 \\
$\mathrm{R}_{w p}(\%)$ & 2.68 & 3.15 & 2.78 \\
$\chi^{2}$ & 1.41 & 3.91 & 1.59 \\
\hline
\end{tabular}



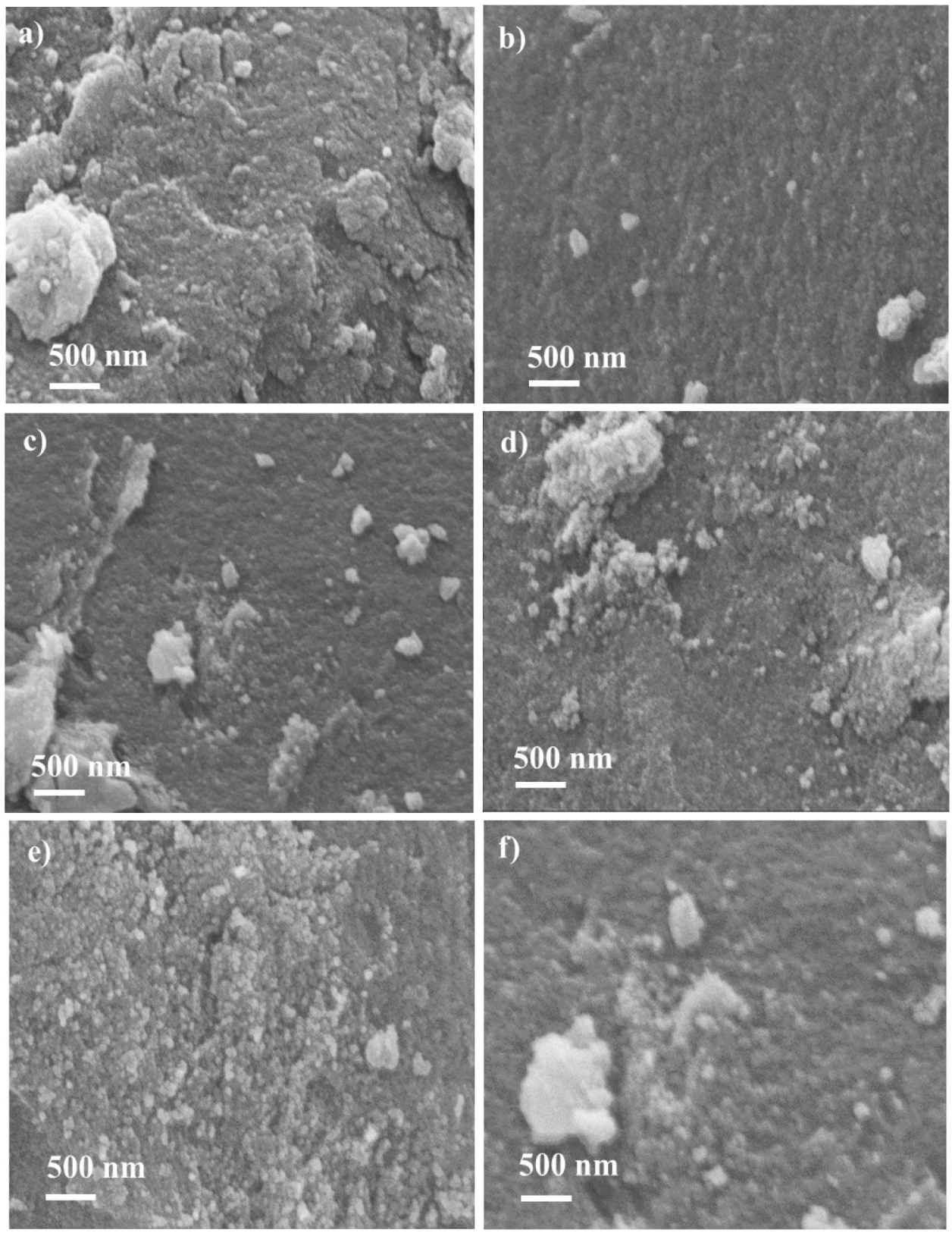

Fig. 4. Secondary electron images of (a) $\mathrm{ZnE}_{1} \mathrm{~N}$, (b) $\mathrm{ZnE}_{3} \mathrm{~N}$, (c) $\mathrm{ZnE}_{5} \mathrm{~N}$, (d) $\mathrm{ZnE}_{1} \mathrm{NK}$, (e). $\mathrm{ZnE}_{3} \mathrm{NK}$, and (f) $\mathrm{ZnE} \mathrm{E}_{5} \mathrm{NK}$.

decreased in crystallite size with the increase of the extract concentration revealed that the secondary metabolites of the Simbang Darah could control the crystal growth.

The structural parameters of the nanoparticles were investigated using the Le Bail refinement method available in the RIETICA program. Initial parameters for the refinement were used from the cubic $\mathrm{F} d 3 \mathrm{~m}$ $\mathrm{ZnFe}_{2} \mathrm{O}_{4}$ (ICSD-158837). Fig. 3 shows Le Bail profile to the XRD patterns of $\mathrm{ZnFe}_{2} \mathrm{O}_{4}$ samples after calcination. All XRD peaks were well-fitted with the Bragg reflections in the $\mathrm{Fd} 3 \mathrm{~m}$ space group, confirming that all samples were single-phase [33]. The refined structural parameters are given in Table 1. Besides, the lattices parameters and cell volume were relatively constant for all samples, demonstrating that the concentration of extract did not change the structure of $\mathrm{ZnFe}_{2} \mathrm{O}_{4}$.

\subsection{SEM analysis}

The morphology of synthesized $\mathrm{ZnFe}_{2} \mathrm{O}_{4}$ nanoparticles was analyzed using SEM instrument. Fig. 4 shows that all secondary electron images of the samples have spherical shapes morphology with some clusters and aggregated nanoparticles. Fig. 4(a-c) demonstrates the morphology of $\mathrm{ZnE}_{1} \mathrm{~N}, \mathrm{ZnE}_{3} \mathrm{~N}$, and $\mathrm{ZnE}_{5} \mathrm{~N}$ particles. The samples have more distinct homogeneity spherical morphologies with smaller particle size and less aggregation. Meanwhile, the $\mathrm{ZnE}_{1} \mathrm{NK}, \mathrm{ZnE}_{3} \mathrm{NK}$, and $\mathrm{ZnE}_{5} \mathrm{NK}$ particles also exhibited spherical morphologies with slightly larger particle size and agglomerations.

Generally, the agglomerating tendency is found in ferrite nanoparticles due to its high surface energy, magnetic nanomaterials [34]. The estimated particle size distribution ranged from 10 to $40 \mathrm{~nm}$ for $\mathrm{ZnE}_{1} \mathrm{~N}, \mathrm{ZnE}_{3} \mathrm{~N}$, and $\mathrm{ZnE}_{5} \mathrm{~N}$, whereas for $\mathrm{ZnE}_{1} \mathrm{NK} \mathrm{ZnE}_{3} \mathrm{NK}$, and $\mathrm{ZnE}_{5} \mathrm{NK}$ is in the range of $20-80 \mathrm{~nm}$. These results are in agreement with [35] which have nanoparticle diameters ranging from $10 \mathrm{~nm}$ to $50 \mathrm{~nm}$ but smaller and homogeneous than that obtained by [34]. The homogeneous shape and the small size of ferrite particles are very beneficial for their photocatalytic activity applications. Smaller grain size has a larger surface area, leading to better interaction with the dye molecules in the liquid medium. Thus, it can be concluded that the morphology of the 


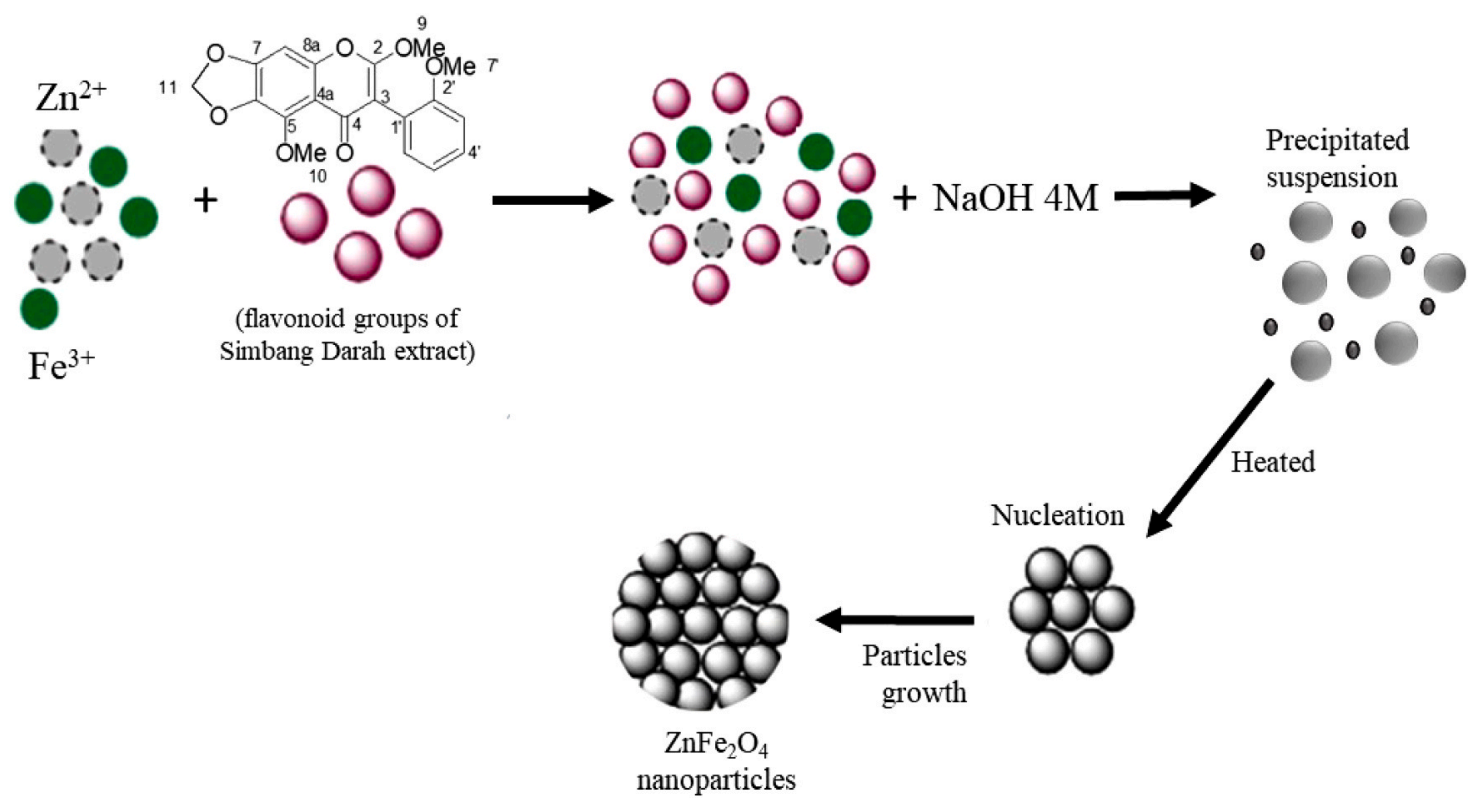

Fig. 5. Schematic diagram of the proposed formation mechanism of $\mathrm{ZnFe}_{2} \mathrm{O}_{4}$ nanoparticles in the presence of Simbang Darah extracts as a capping agent.
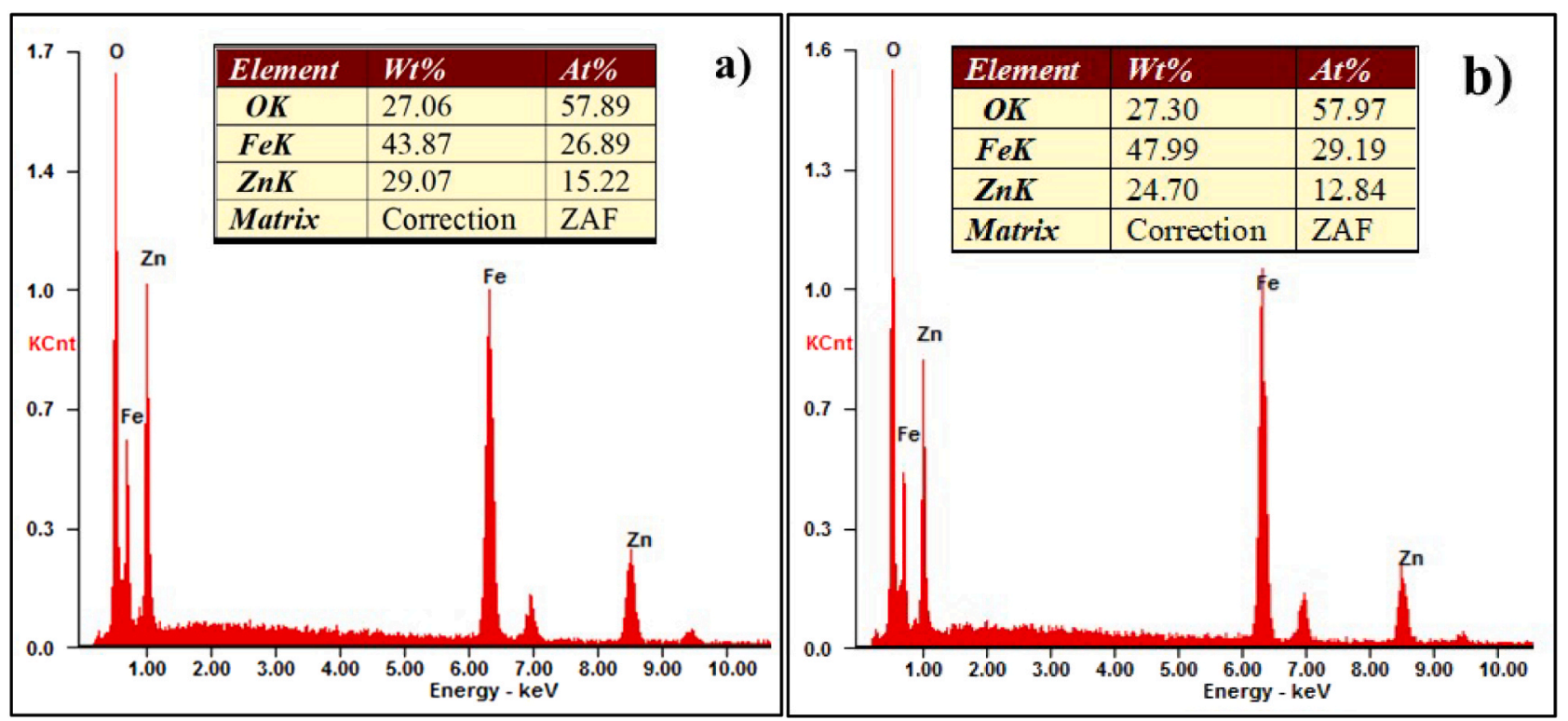

Fig. 6. $\mathrm{EDX}$ spectrum of $\mathrm{ZnE}_{1} \mathrm{~N}$ (a) and $\mathrm{ZnE}_{1} \mathrm{NK}$ (b).

materials is affected by Simbang Darah leaf extract concentration and the calcination process. The proposed mechanism towards the formation of $\mathrm{ZnFe}_{2} \mathrm{O}_{4}$ nanoparticles in the presence of Simbang Darah extracts as the capping agent is presented in Fig. 5.

\subsection{EDX analysis}

The composition of the elements in the ferrites obtained from EDX is shown in Fig. 6. The EDX spectrum shows the presence of Zn, Fe, and O elements only in both samples. The weight percentages of $\mathrm{Zn}, \mathrm{Fe}$, and $\mathrm{O}$ elements in $\mathrm{ZnE}_{1} \mathrm{~N}$ particles were $27.06 \%, 43.87 \%$, and $29.07 \%$, respectively, whereas $\mathrm{ZnE}_{1} \mathrm{NK}$ were $24.70 \%, 47.99 \%$, and $27.3 \%$, respectively. $\mathrm{Fe}$ and $\mathrm{Zn}$ 's percentage in the samples suggested that the ratio of $\mathrm{Fe}: \mathrm{Zn}$ atoms was close to $2: 1$, confirming the formation of $\mathrm{ZnFe}_{2} \mathrm{O}_{4}$ ferrite spinel structure. As shown in the spectra, the peaks are ascribed to the photocatalyst elements, and no other elements are found.
It indicated the high purity of $\mathrm{ZnFe}_{2} \mathrm{O}_{4}$ samples.

\subsection{TEM analysis}

Detailed morphology and structure of $\mathrm{ZnFe}_{2} \mathrm{O}_{4}$ were investigated using TEM (Fig. 7). Fig. 7(a-b) show the TEM photographs of $\mathrm{ZnE}_{1} \mathrm{~N}$ that revealed particle-like shape with a uniform size distribution in the range of 6-8 nm. This finding correlates to the data obtained using XRD. Fig. $7 \mathrm{~b}$ inset shows the particles size distribution and particle count histogram, resulting in more particles having a grain of $6 \mathrm{~nm}$. The selected area electron diffraction (SAED) pattern (Fig. 7d) shows the spot type pattern as an indication of good crystallinity. The distinct lattice fringes were evident in the high-resolution TEM (HRTEM) image (Fig. 7c) suggesting that $\mathrm{ZnFe}_{2} \mathrm{O}_{4}$ is good crystalline in nature. The crystal planes were also clearly visible from the images, and the lattice plane fringes were used to calculate the d-spacing values. The d-spacing 

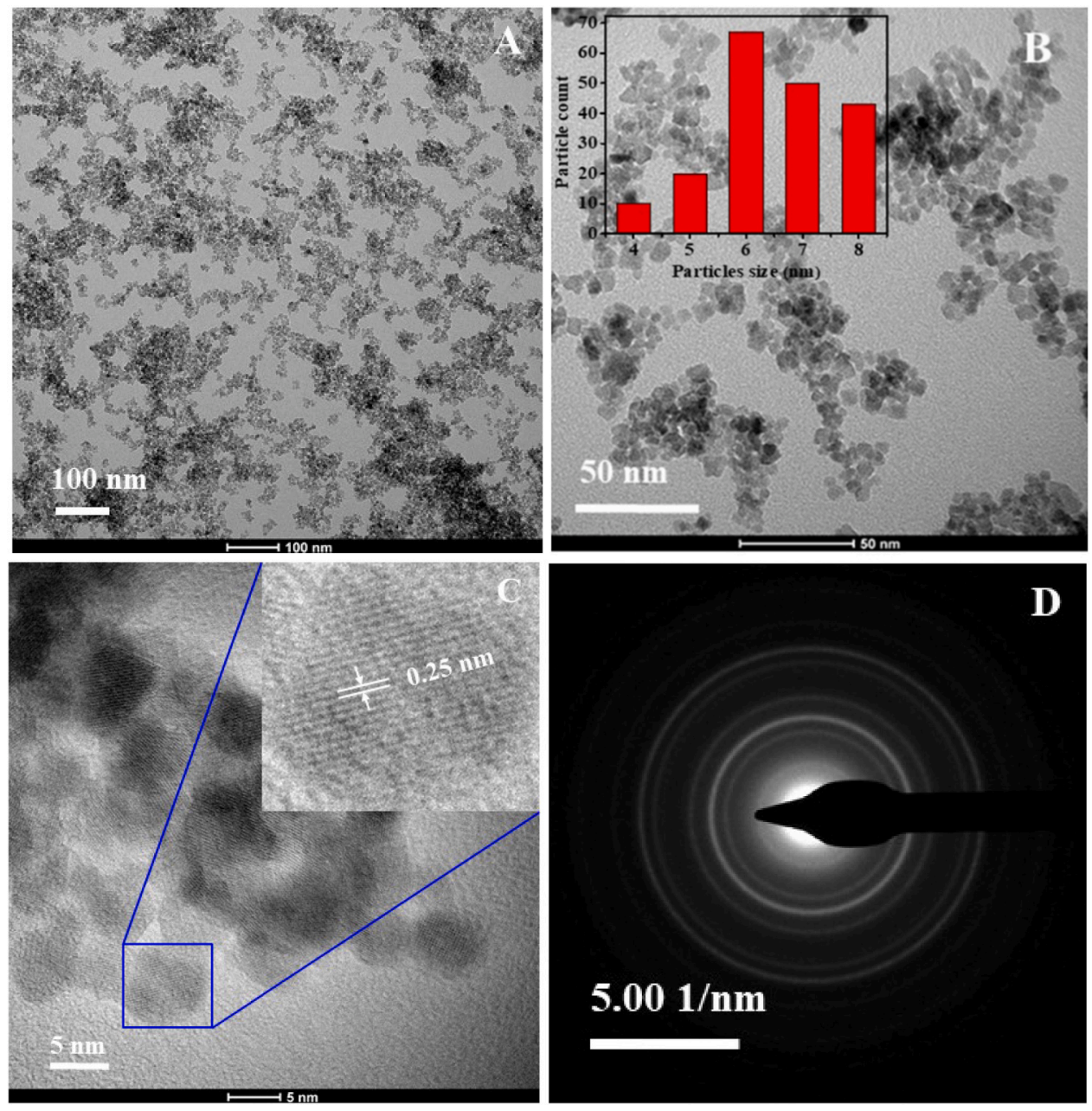

Fig. 7. TEM micrograph (a-b), HRTM micrograph (c), and SAED pattern of $\mathrm{ZnE}_{1} \mathrm{~N}$ (d). Insert in b) is the histogram of particles distribution.

of $0.25 \mathrm{~nm}$ corresponded to the (311) crystal plane of $\mathrm{ZnFe}_{2} \mathrm{O}_{4}$. This value aligned with the value of $2.5 \AA$, calculated using the Bragg's equation using the XRD result of a representative $\mathrm{ZnFe}_{2} \mathrm{O}_{4}$ [36]. This finding is further supported by the presence of intense rings that were well resolved in the SAED pattern.

\subsection{XPS analysis}

The X-ray photoelectron spectroscopy (XPS) measurement was used to analyze the chemical state of the elements in the $\mathrm{ZnE}_{1} \mathrm{~N}$ spinel ferrite. The results are displayed in Fig. 8(a and b). From the full spectrum of $\mathrm{ZnFe}_{2} \mathrm{O}_{4}$ in Fig. 8a, it can be observed that the sample consisted of $\mathrm{Zn}$, $\mathrm{Fe}, \mathrm{O}$, and $\mathrm{C}$ binding energies with no other impurities. In Fig. $8 \mathrm{~b}$, the binding energies of $\mathrm{Zn} 2 \mathrm{p}_{1 / 2}$ and $\mathrm{Zn} 2 \mathrm{p}_{3 / 2}$ are $1045 \mathrm{eV}$ and $1022 \mathrm{eV}$, respectively. Compared with the standard spectrum, these energies are suitable for $\mathrm{Zn}^{2+}$ [37]. The spectrum of Fe shows two peaks located at 708 , and $720 \mathrm{eV}$ for $2 \mathrm{p}_{3 / 2}$ and $2 \mathrm{p}_{1 / 2}$ corresponding to $\mathrm{Fe}^{3+}$ ion in the spinel ferrite. The presence peak of $\mathrm{C} 1 \mathrm{~s}$ at $284.8 \mathrm{eV}$ was introduced during the reaction process or exogenously substances during testing.

\subsection{UV-Vis DRS analysis}

The optical properties of $\mathrm{ZnFe}_{2} \mathrm{O}_{4}$ nanoparticles synthesized via the hydrothermal method and further calcined at $500{ }^{\circ} \mathrm{C}$ were investigated using UV-Visible reflectance spectroscopy. The samples' UV-DRS spectrum shows a strong absorption band at the visible light area (Fig. $8 \mathrm{c}$ ). The band gap energy of the $\mathrm{ZnFe}_{2} \mathrm{O}_{4}$ nanoparticles was evaluated from the spectrum using the Kubelka-Munk model [38]. For the band gap determination, a graph (a Taucplot) is plotted between $[\mathrm{F}(\mathrm{R}) \mathrm{h} \nu]^{2}$ and energy $(\mathrm{eV})$, and the intercept is the band gap energy as shown in Fig. 8d. The band gap energy for all samples is shown in Table 1. From Table 1 , it can be seen that the band gap energies are in the range $2.05-2.11 \mathrm{eV}$, which are in good agreement with the previously reported values [14] using sugarcane juice extract and another report [39] using Hibiscus rosa sinensis extract. The band gaps of the synthesized $\mathrm{ZnFe}_{2} \mathrm{O}_{4}$ are in the range of $2.05-2.11 \mathrm{eV}$, which are expected to reduce the possibility of recombination of electrons from the conduction band to valence band and thus improve the catalytic activity. The band gap variation depends on various factors such as crystallinity, crystallite size, structural parameters, lattice strain, and the presence of defects or impurities $[8,38]$. In our case, the variation of band gap correlates with the crystallinity and crystallite size [21]. The observed blue shift in Fig. 9a is mainly attributed to the smaller crystallite size of the samples.

\subsection{VSM analysis}

The magnetization curves of $\mathrm{ZnFe}_{2} \mathrm{O}_{4}$ and the value of magnetic saturation $(M s)$, magnetic remanent $(\mathrm{Mr})$ and coercive field $(\mathrm{Hc})$ before and after calcination are shown in Fig. 9 and Table 2. The hysteresis curve shows that all $\mathrm{ZnFe}_{2} \mathrm{O}_{4}$ un-calcined samples have paramagnetic behavior.

The $M s$ value for the un-calcined samples increased (1.69, 1.74, and $2.08 \mathrm{emu} / \mathrm{g}$ ) as the crystallite size decrease. Similarly, $M s$ increased when the sample was calcined at $500{ }^{\circ} \mathrm{C}$ because of the arrangement of atoms and dipoles in the crystal lattice as the temperature is raised. It was observed that all $M s$ values of the synthesized samples are smaller 

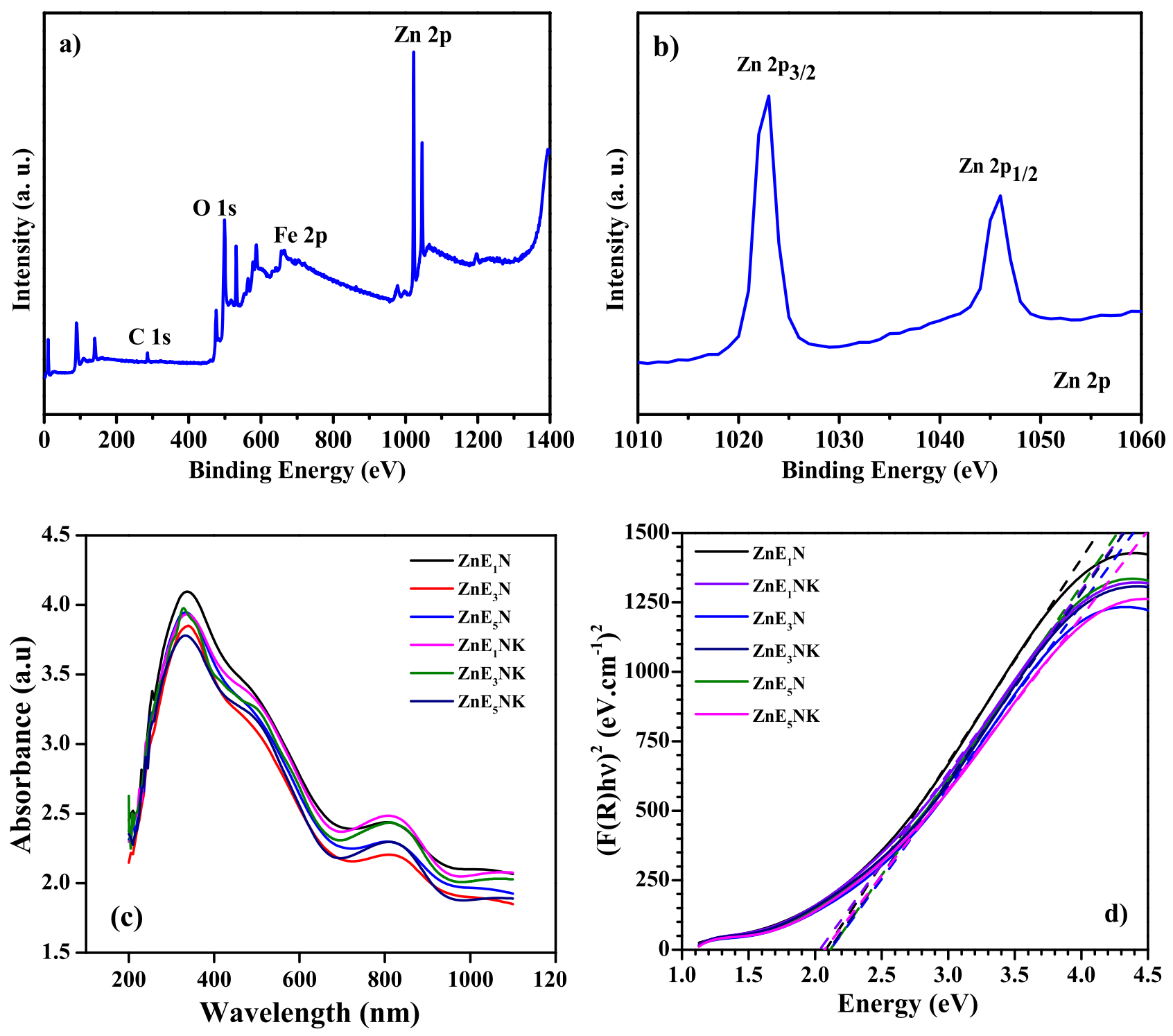

Fig. 8. XPS spectrum of $\mathrm{ZnE}_{1} \mathrm{~N}$ (a and b), DRS UV-Vis spectrum (c) and band gap energy (d) of samples.

than those obtained by [38]. Moreover, $M s, M r$, and $H c$ values obtained in this experiment indicated that the Simbang Darah leaf extract concentrations affect the crystallinity and magnetic properties of $\mathrm{ZnFe}_{2} \mathrm{O}_{4}$. Furthermore, the calcined samples of $\mathrm{ZnE}_{1} \mathrm{NK}, \mathrm{ZnE}_{3} \mathrm{NK}$, were paramagnetic, while $\mathrm{ZnE}_{5} \mathrm{NK}$ exhibited superparamagnetic behavior. The calcination process of $\mathrm{ZnFe}_{2} \mathrm{O}_{4}$ will change ferrite behavior from paramagnetic to superparamagnetic. The presence of magnetic properties confirmed the efficacy of zinc ferrite as a photocatalyst because it can be separated from the liquid using an external magnetic field. Thus, these materials can be used for subsequent photocatalytic processes.

\subsection{FTIR analysis}

The structure of $\mathrm{ZnFe} 2 \mathrm{O} 4$ ferrite nanoparticles before (a) and after calcination (b) was further studied by characterizing the samples using FTIR as shown in Fig. 10. Two prominent absorption bands of the spinel ferrite were observed in all spectra of the samples ranging from 300 to $600 \mathrm{~cm}^{-1}$ indicating the spinel ferrite of $\mathrm{ZnFe}_{2} \mathrm{O}_{4}$. Apart from that, strong absorbance bands around $540-580 \mathrm{~cm}^{-1}$ corresponded to $\mathrm{Zn}-\mathrm{O}$ interaction at the tetrahedral site, whereas the bands around
$300-450 \mathrm{~cm}^{-1}$ were attributed to the stretching of $\mathrm{Fe}-\mathrm{O}$ in the octahedral site [14].

The spectrums of $\mathrm{ZnE}_{1} \mathrm{~N}, \mathrm{ZnE}_{3} \mathrm{~N}, \mathrm{ZnE}_{5} \mathrm{~N}, \mathrm{ZnE}_{1} \mathrm{NK}, \mathrm{ZnE}_{3} \mathrm{NK}$, and $\mathrm{ZnE}_{5} \mathrm{NK}$ at $414,424,416,430,430$, and $434 \mathrm{~cm}^{-1}$ respectively, correspond to the intrinsic stretching vibration of $\mathrm{Fe}-\mathrm{O}$ at the octahedral position, whereas the other absorption bands at 546, 558, 546, 548, 550, and $560 \mathrm{~cm}^{-1}$ correspond to the stretching of $\mathrm{Zn}-\mathrm{O}$ at the tetrahedral position. The adsorption band shifted with the decrease of particle size and with the increase of temperature. The difference in the absorption region was probably due to the varying $\mathrm{Zn}-\mathrm{O}$ bond distance in the $\mathrm{ZnFe}_{2} \mathrm{O}_{4}$ spinel structure. Besides, the spectrum also showed that the intensity of the calcined sample (Fig. 10b) was sharper than the uncalcined sample (Fig. 10a). This observation is probably due to the calcination process that formed a regular ferrite spinel structure. From the obtained spectrum bands, it can be concluded that the resulting sample is spinel ferrite. The peaks around $1400-1600 \mathrm{~cm}^{-1}$ for the uncalcined sample indicated the presence of bending and stretching of $\mathrm{C}^{=} \mathrm{O}, \mathrm{C}-\mathrm{O}, \mathrm{OH}$, and $\mathrm{COO}^{-}$derivatives of the secondary metabolites and other organic compounds contained in the Simbang Darah leaf extract [7]. 

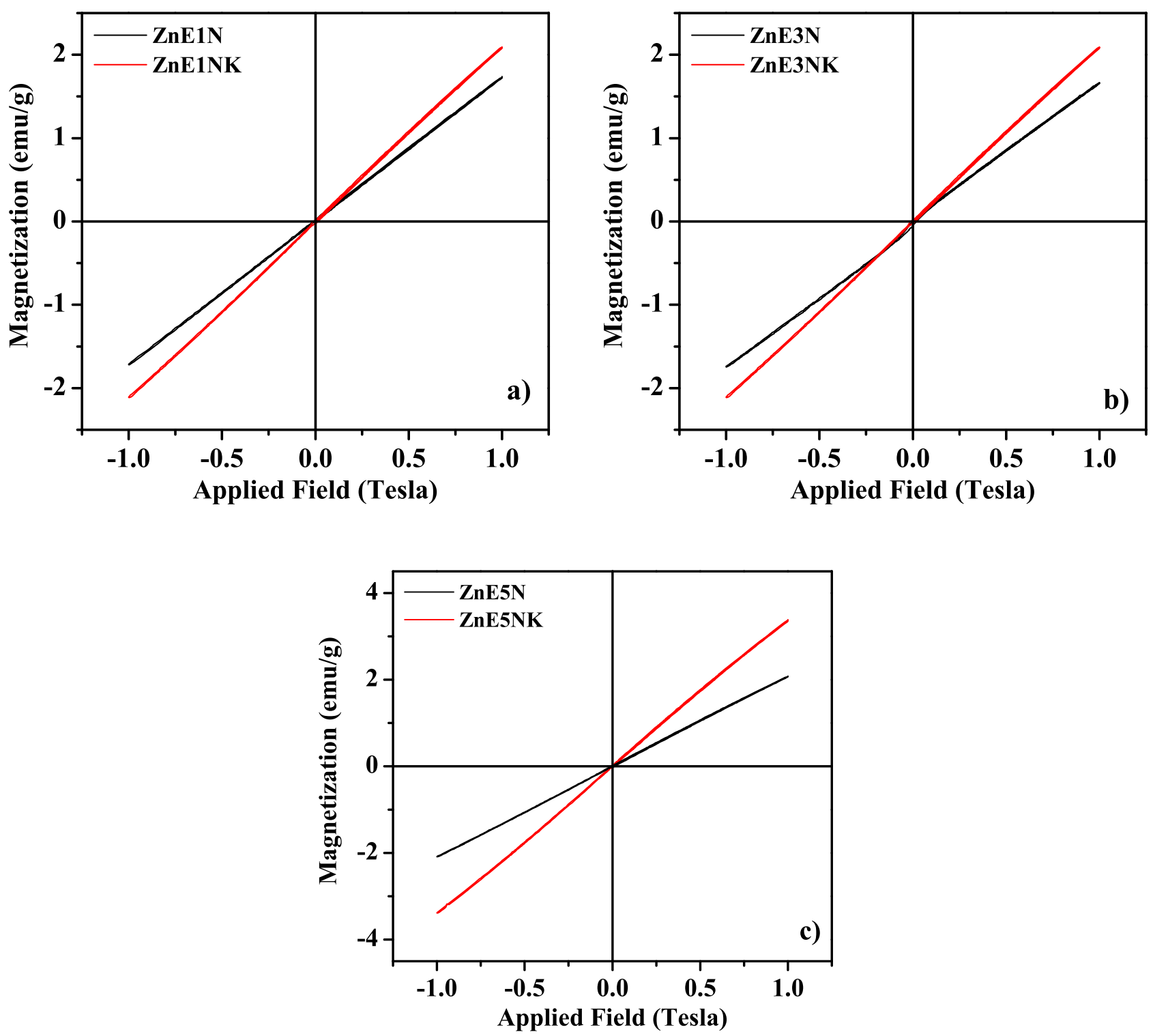

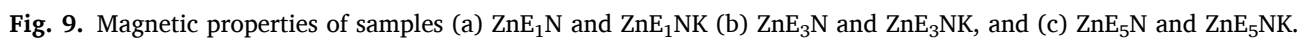

Table 2

Crystallite size, band gap, and magnetic behavior of Zn-ferrites before and after calcination.

\begin{tabular}{lcllll}
\hline Catalysts & $\begin{array}{l}\text { Crystallite } \\
\text { Size }\end{array}$ & $\begin{array}{l}\text { Band } \\
\text { gap }\end{array}$ & $\begin{array}{l}\text { Magnetic } \\
\text { saturation } \\
(\mathrm{Ms}) \\
(\mathrm{emu} / \mathrm{g})\end{array}$ & $\begin{array}{l}\text { Magnetic } \\
\text { remanent } \\
(\mathrm{Mr})\end{array}$ & $\begin{array}{l}\text { Coercivity } \\
\text { field }(\mathrm{Hc})\end{array}$ \\
\hline $\mathrm{ZnE}_{1} \mathrm{~N}$ & 7.2 & 2.08 & 1.69 & 0.006 & Tesla \\
$\mathrm{ZnE}_{3} \mathrm{~N}$ & 6.8 & 2.11 & 1.74 & 0.026 & 0.006 \\
$\mathrm{ZnE}_{5} \mathrm{~N}$ & 6.2 & 2.12 & 2.08 & 0.014 & 0.011 \\
$\mathrm{ZnE}_{1} \mathrm{NK}$ & 15.8 & 2.05 & 2.07 & 0.013 & 0.004 \\
$\mathrm{ZnE}_{3} \mathrm{NK}$ & 16.9 & 2.11 & 2.11 & 0.011 & 0.006 \\
$\mathrm{ZnE}_{5} \mathrm{NK}$ & 14.4 & 2.10 & 3.36 & 0.007 & 0.006 \\
\hline
\end{tabular}

\subsection{BET analysis}

The nitrogen adsorption-desorption isotherms of the $\mathrm{ZnE}_{1} \mathrm{~N}$ sample was measured using the Brunauer-Emmett-Teller (BET) technique to investigate the specific surface area and porous structure of the $\mathrm{ZnE}_{1} \mathrm{~N}$ and $\mathrm{ZnE}_{1} \mathrm{NK}$ (Fig. 11). The findings revealed the specific relation between the adsorbate's concentration and its adsorption degree with the adsorbent surface [16]. According to IUPAC classification, the $\mathrm{ZnE}_{1} \mathrm{~N}$ and $\mathrm{ZnE}_{1} \mathrm{NK}$ are type IV isotherms, characterized by their mesoporous structure [40].

The branch preceding the hysteresis loop corresponded to monolayer adsorption whereas the hysteresis loop is associated with capillary condensation in relatively coarse pores or the interstices between the particles of the zinc ferrite spinel. The increase in the adsorption branch with the sharp decline in the desorption branch observed at P/Po was greater than 0.6 due to the capillary condensation of $\mathrm{N}_{2}$ into the mesoporous structure, indicating good homogeneity of the nanocomposite [41]. The specific surface area of samples obtained from the nitrogen adsorption-desorption measurement was 134.3 and $125.5 \mathrm{~m}^{2} / \mathrm{g}$ for $\mathrm{ZnE}_{1} \mathrm{~N}$, and 114.28 and $110.27 \mathrm{~m}^{2} / \mathrm{g}$ for $\mathrm{ZnE}_{1} \mathrm{NK}$, respectively. The decreased surface area of $\mathrm{ZnE}_{1} \mathrm{NK}$ after calcination may be attributed to the recrystallization of the zinc ferrite and subsequent increase in average crystallite size [16]. The total pore volume of $\mathrm{ZnE}_{1} \mathrm{~N}$ is $0.265 \mathrm{cc} / \mathrm{g}$ and $0.250 \mathrm{cc} / \mathrm{g}$ for $\mathrm{ZnE}_{1} \mathrm{NK}$. The samples' average pore diameter calculated using the Barrett-Joyner-Halenda equation was 1.69 and $1.71 \mathrm{~nm}$ for $\mathrm{ZnE}_{1} \mathrm{~N}$ and $\mathrm{ZnE}_{1} \mathrm{NK}$, respectively. The increased pore size after calcination may be due to the particles' rearrangement that led to the loss of the actual pores. Thus, the large surface area would 

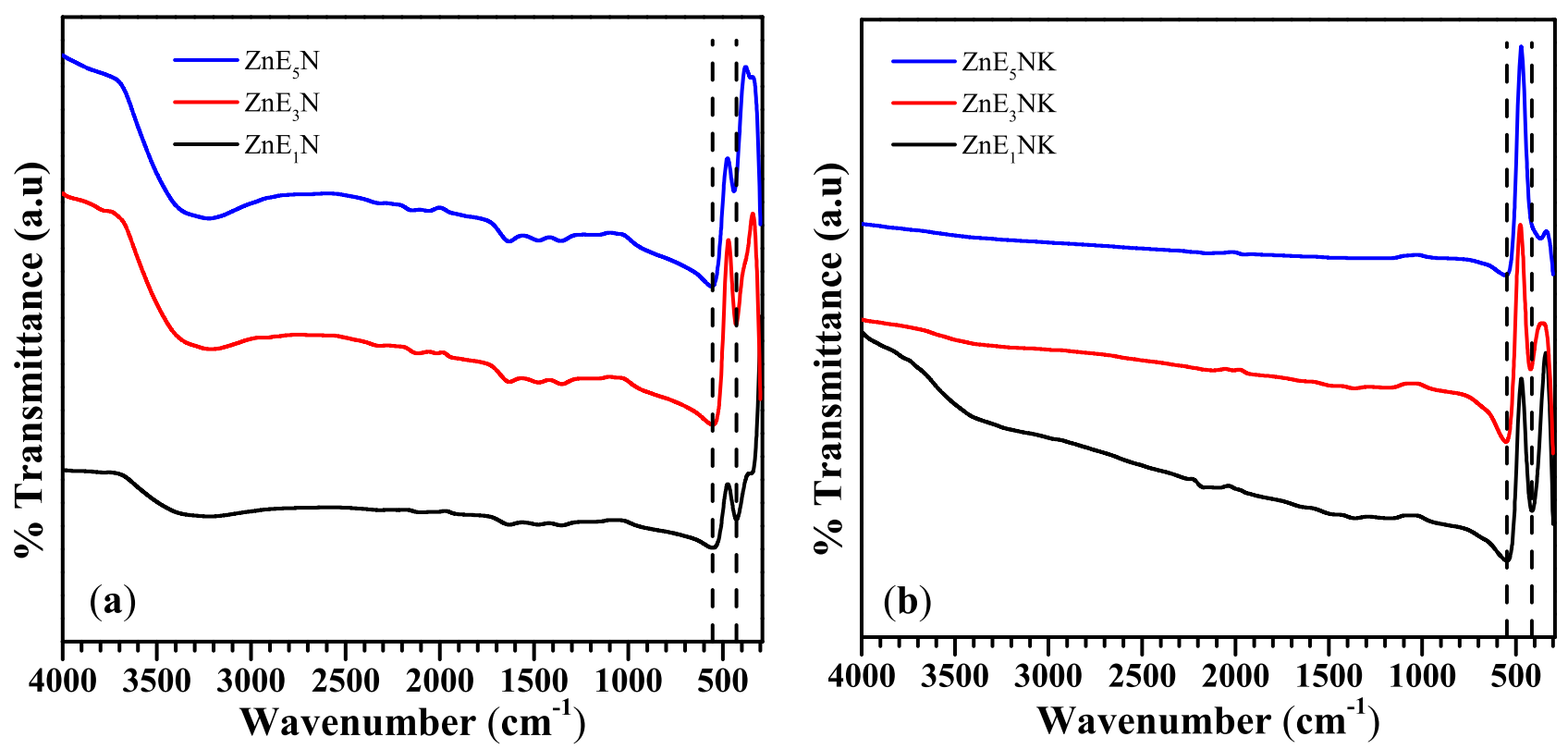

Fig. 10. FTIR spectrums of $\mathrm{ZnFe}_{2} \mathrm{O}_{4}$ before (a) and after calcination (b).

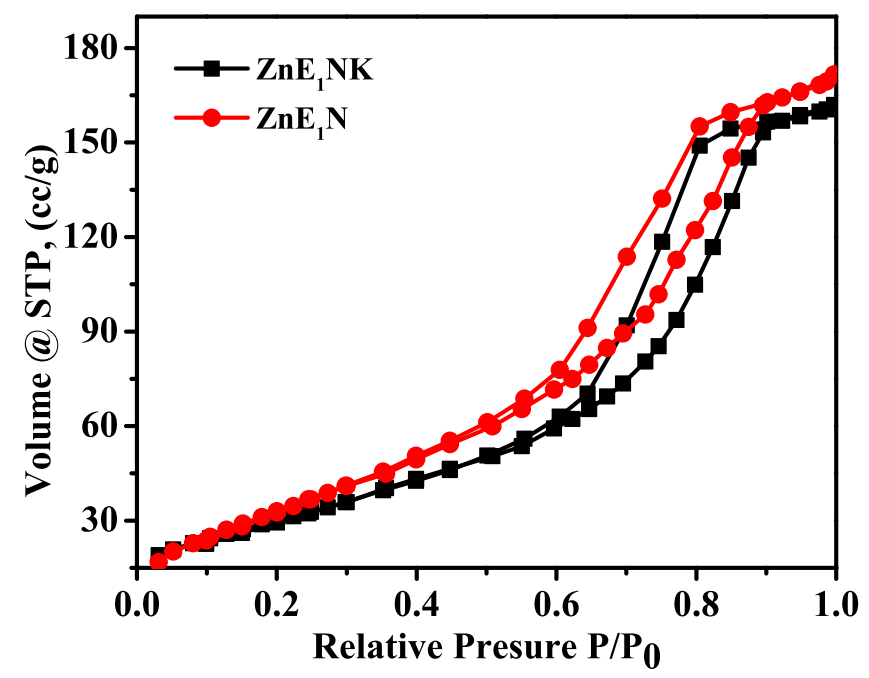

Fig. 11. Nitrogen adsorption-desorption isotherms of the $\mathrm{ZnE}_{1} \mathrm{~N}$ and $\mathrm{ZnE} \mathrm{E}_{1} \mathrm{NK}$.

make this material useful in photocatalytic processes.

\subsection{Photocatalytic activity}

Photocatalytic activity of the zinc ferrite prepared samples was determined based on the degradation of direct red 81 dyes using direct sunlight as a light source (Fig. 12). The experiment was carried out in triplicates. Sunlight is used for the photocatalytic process because it is an abundant, low-cost, and environmentally friendly, renewable source of clean energy. Fig. 12a shows the photocatalytic activity of all prepared samples on the degradation of direct red 81 dye under direct sunlight. The results showed that all catalysts have good activity against the degradation of direct red 81 dyes. The highest percentage of degradation was obtained using $\mathrm{ZnE}_{1} \mathrm{~N}$ as expected because of its smaller particle size and homogeneous morphology compared to other samples that contain more active sites to interact with the light to produce hydroxide radicals as illustrated in the electron images (SEM and TEM images). Hydroxyl radicals are known to be responsible for the photodegradation process of organic pollutants in the presence of natural sunlight.
The effect of dye concentration on the rate of degradation was determined by varying the concentration of direct red 81, as shown in Fig. $12 \mathrm{~b}$ using $\mathrm{ZnE}_{1} \mathrm{~N}$ and $\mathrm{ZnE}_{1} \mathrm{NK}$ as catalysts. The optimal concentration was obtained at $30 \mathrm{mg} \mathrm{L}^{-1}$ with degradation percentage of $99.8 \%$ and $95.8 \%$ for $2 \mathrm{~h}$ using $\mathrm{ZnE}_{1} \mathrm{~N}$ and $\mathrm{ZnE}_{1} \mathrm{NK}$, respectively. Meanwhile, Fig. 12c shows the effect of irradiation time on the degradation percentage of direct red 81 dyes in the presence of $\mathrm{ZnE}_{1} \mathrm{~N}$ and $\mathrm{ZnE}_{1} \mathrm{NK}$. It was found that the degradation of dyes increased with irradiation time since the amount of $\mathrm{OH} \cdot$ radicals formed increased with time. The $\mathrm{OH}$ • radicals were active groups that played a role in breaking down the dyes molecules into simpler compounds (ex: $\mathrm{H}_{2} \mathrm{O}$ and $\mathrm{CO}_{2}$ ) [42]. Furthermore, the maximum degradation percentage (99.66\%) was obtained using $\mathrm{ZnE}_{1} \mathrm{~N}$ for $2 \mathrm{~h}$ under solar irradiation. Since $\mathrm{ZnE}_{1} \mathrm{~N}$ catalyst has higher dye decomposition efficiency than its calcined counterpart, all further experiments were performed using $\mathrm{ZnE}_{1} \mathrm{~N}$.

An important property of photocatalysts is their recovery and repeated usage in catalytic processes. To test this characteristic, the $\mathrm{ZnE}_{1} \mathrm{~N}$ catalyst was repeatedly used in the photodegradation process of direct red 81 dyes under natural sunlight. In between each cycle, the catalysts were recovered via filtration, washed with distilled water, and dried at $105{ }^{\circ} \mathrm{C}$. Fig. $12 \mathrm{~d}$ shows the degradation percentage of direct red 81 dyes using $\mathrm{ZnE}_{1} \mathrm{~N}$ for four cycles which demonstrated that the catalyst remained fairly effective after being used for 4 cycles, indicating its stability and ability to be used repeatedly. Photodegradation of dyes/ organic pollutants by different catalysts can be seen in Table 3 .

The kinetics for photocatalysts are described in the LangmuirHinshelwood model, which can be expressed by $\ln \left(C_{0} / C_{t}\right)=k t$ when the dye concentration is relatively low (where $C_{0}$ is the initial concentration of dye, $C_{t}$ is the concentration at time $t$ and $k$ is the apparent firstorder rate constant). By plotting $\ln \left(C_{0} / C_{t}\right)$ vs irradiation time, $t, k$ can be determined, which can be used as an assessment index for evaluating the photocatalytic efficiency of synthesized materials. Based on Fig. 12e, it was observed that the kinetic plot for catalysts was somewhat linear. Hence, the photodegradation reaction of direct red 81 dyes with $\mathrm{ZnE}_{1} \mathrm{~N}$ catalyst is of the first order with an $r$ value of 0.985 and $k=0.01204 \mathrm{~s}^{-1}$.

The primary mechanism of photocatalytic activity (Fig. 13) in the presence of $\mathrm{ZnFe}_{2} \mathrm{O}_{4}$ as a catalyst was initiated through the electrons transfer $\left(\mathrm{e}^{-}\right)$from the valence band $(\mathrm{VB})$ to the conduction band (CB) if a certain amount of photon energy was absorbed by the electrons, leaving a hole $\left(\mathrm{h}^{+}\right)$in the VB. Then, CB's electrons reacted with $\mathrm{O}_{2}$ in the water to form superoxide radical anions through a reduction reaction. 

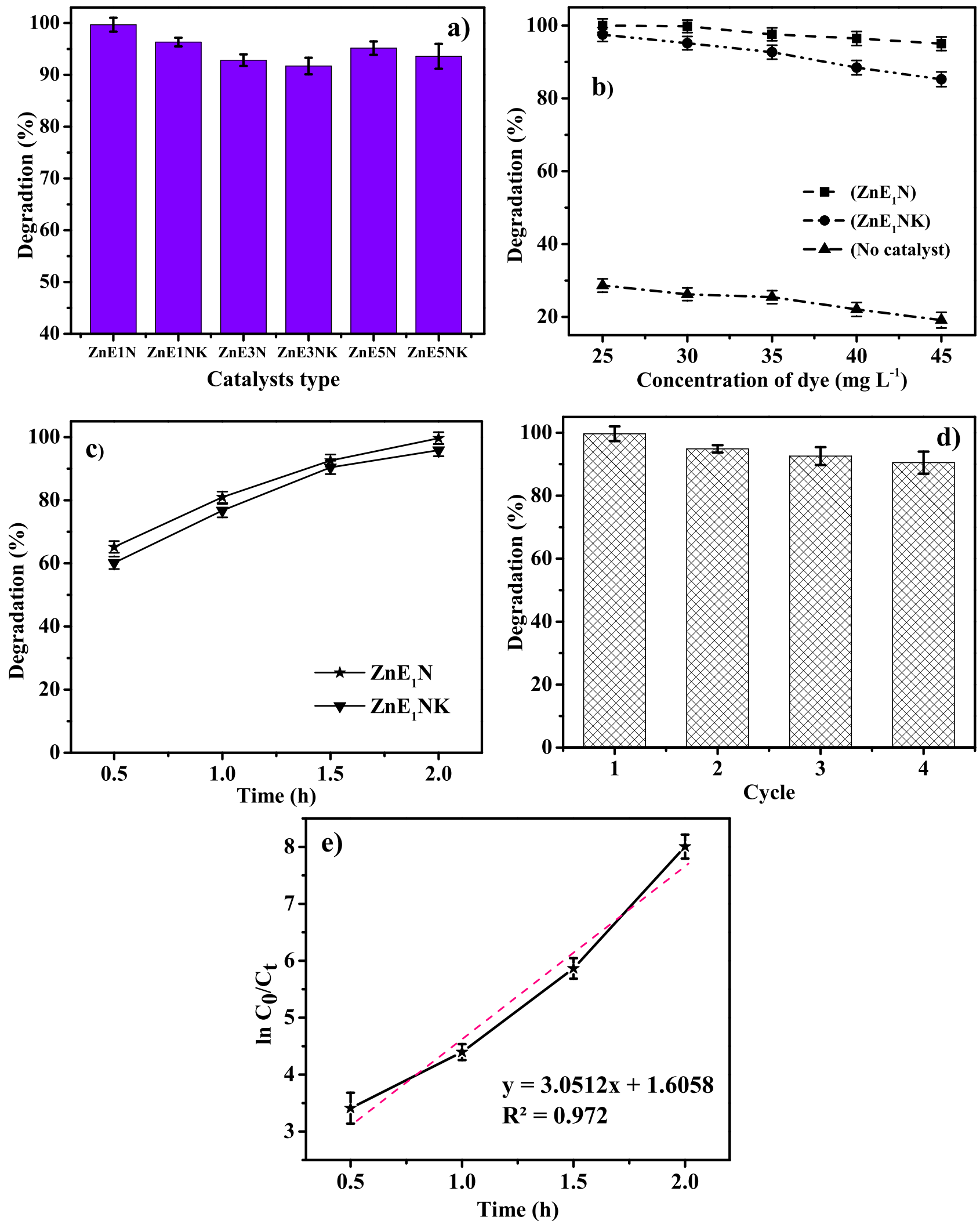

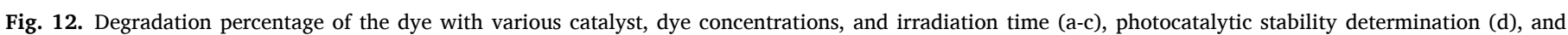
reaction kinetics of the photocatalytic process (e).

Superoxide radicals then underwent protonation to form $\mathrm{H}_{2} \mathrm{O}_{2}$, which then dissociated to form $\mathrm{OH}$ - radicals. This radical avoided the recombination of $\mathrm{e}^{-} / \mathrm{h}^{+}$pairs and participated in the oxidation process. On the other hand, $\mathrm{OH}^{-}$derived from the decomposition of water molecules reacted with the hole $\left(\mathrm{h}^{+}\right)$in $\mathrm{VB}$ through oxidation reactions, forming $\mathrm{OH}$ - radicals. Furthermore, $\mathrm{OH} \cdot$ radicals attacked the organic pollutants or dyes to form unstable intermediates and broke them down into simple molecules, i.e., water, and carbon dioxide gas [46]. 
Table 3

Comparing photodegradation of dyes/organic pollutants by different catalysts.

\begin{tabular}{|c|c|c|c|c|c|}
\hline No & Catalyst & Synthesis method & Name of dyes/ organic pollutant & $\%$ of degradation & Ref. \\
\hline 1. & $\mathrm{ZnFe}_{2} \mathrm{O}_{4}$ & Green synthesis & Direct Red 81 & 99.66 & This work \\
\hline 2. & $\mathrm{ZnFe}_{2} \mathrm{O}_{4}$ & Co-precipitation & Methylene Blue & 99 & [11] \\
\hline 3. & $\mathrm{ZnFe}_{2} \mathrm{O}_{4}$ & Combustion route & Rhodamine B, Methylene Blue & $\begin{array}{l}98 \\
95\end{array}$ & [14] \\
\hline 4. & $\mathrm{ZnFe}_{2} \mathrm{O}_{4}$ & Co-precipitation & Acid Blue 113 & 92 & {$[16]$} \\
\hline 5. & $\mathrm{ZnFe}_{2} \mathrm{O}_{4}$ & Green method & $\begin{array}{l}\text { Methylene Blue } \\
\text { Evan Blue }\end{array}$ & $\begin{array}{l}99.6 \\
89\end{array}$ & {$[21]$} \\
\hline 6. & $\mathrm{ZnFe}_{2} \mathrm{O}_{4}$ & Green synthesis & Tetracycline & 80 & [34] \\
\hline 7. & $\mathrm{ZnFe}_{2} \mathrm{O}_{4}$ & Combustion & $\begin{array}{l}\text { Congo Red } \\
\text { Rhodamine B }\end{array}$ & $\begin{array}{l}95 \\
93.6\end{array}$ & [9] \\
\hline 8. & $\mathrm{ZnFe}_{2} \mathrm{O}_{4}$ & Hydrothermal & Methylene blue & 90 & [43] \\
\hline 9. & $\mathrm{NiFe}_{2} \mathrm{O}_{4} /$ natural mineral & Microwave hydrothermal & Sodium dodecyl benzene sulfonate & 100 & [13] \\
\hline 10. & $\begin{array}{l}\mathrm{ZnFe}_{2} \mathrm{O}_{4} / \\
\text { Polyaniline }\end{array}$ & Co-precipitation & Rhodamine B & 85 & [10] \\
\hline 11. & $\mathrm{ZnO}-\mathrm{CoFe}_{2} \mathrm{O}_{4}$ & Green method & Direct Yellow & 95 & {$[28]$} \\
\hline 12. & $\mathrm{MnFe}_{2} \mathrm{O}_{4}$ & Green method & Direct Red 81 & 56.5 & [30] \\
\hline 13. & $\mathrm{SnFe}_{2} \mathrm{O}_{4} /$ Polypyrrole & Sonication & Tartrazine & 100 & [44] \\
\hline 14. & $\mathrm{NiFe}_{2} \mathrm{O}_{4}$ & Co-precipitation & Methyl Orange & 72.66 & {$[45]$} \\
\hline
\end{tabular}

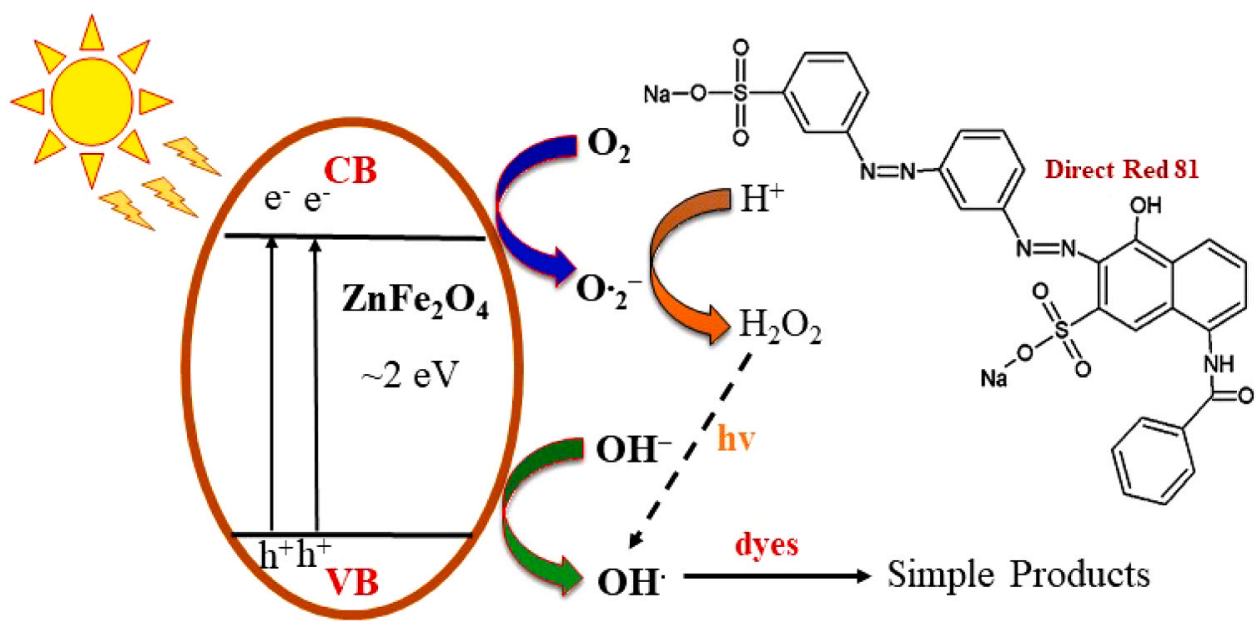

Fig. 13. The proposed photocatalytic mechanism of the direct red 81 using $\mathrm{ZnFe}_{2} \mathrm{O}_{4}$ as a catalyst.
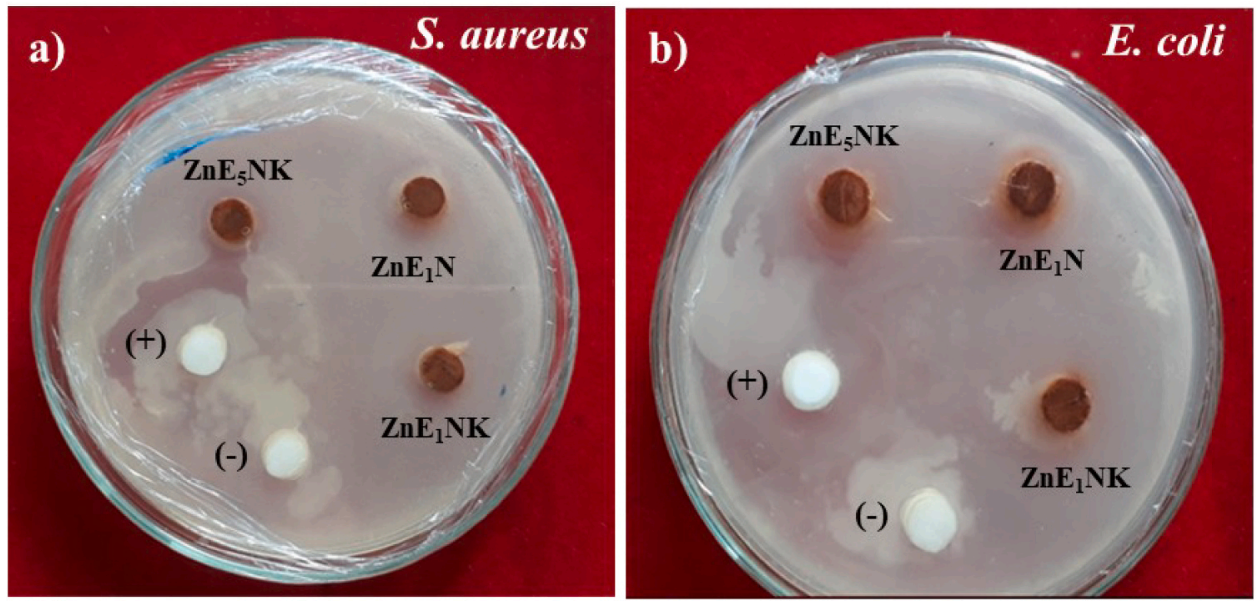

Fig. 14. Antibacterial activity of $\mathrm{ZnFe}_{2} \mathrm{O}_{4}$ on $S$. aureus (a) and E. coli (b). 


\subsection{Antibacterial activity}

The antibacterial assay for $\mathrm{ZnE}_{1} \mathrm{~N}$, $\mathrm{ZnE}_{1} \mathrm{NK}$, and $\mathrm{ZnE}_{5} \mathrm{NK}$ samples was conducted using Gram-positive (S. aureus) and Gram-negative (E. coli) as pathogens. The results are shown in Fig. 14. $\mathrm{ZnE}_{1} \mathrm{~N}, \mathrm{ZnE}_{1} \mathrm{NK}$, and $\mathrm{ZnE}_{5} \mathrm{NK}$ ferrite samples showed positive antibacterial activity against S. aureus with an inhibition zone of $10.9,10$, and $9.4 \mathrm{~mm}$ in respectively, whereas for $E$. coli were 9.6, 4.9, and $7.5 \mathrm{~mm}$, respectively. Amoxicillin and water were used as a positive and negative control in this experiment. The bacterial activity of zinc ferrite depends on the size, morphology, chemical molecule diffusion ability, and the discharge of metal ions. In addition, the surface area is crucial in the elevated and promising activity of $\mathrm{ZnFe}_{2} \mathrm{O}_{4}$ nanoparticles against all the tested pathogenic microbes. There are many reasonable mechanisms for the antimicrobial action of $\mathrm{ZnFe}_{2} \mathrm{O}_{4}$ nanoparticles, including radical groups generated through the redox reactions during the photocatalytic process attack the bacteria's cell membrane components and inhibit the growth of these microorganisms [47].

\section{Conclusion}

The ferrite spinel of $\mathrm{ZnFe}_{2} \mathrm{O}_{4}$ nanostructures has been successfully synthesized using Simbang Darah extract as a capping agent via the hydrothermal method. Characterization using several instruments showed that the samples were in the form of homogeneous spherical granules. The synthesized zinc ferrite nanoparticles exhibited paramagnetic and absorbent behavior under the visible light with a band gap energy of $\sim 2 \mathrm{eV}$. The $\mathrm{ZnFe}_{2} \mathrm{O}_{4}$ nanoparticles showed effective photodegradation for direct red 81 at $99.66 \%$ for $2 \mathrm{~h}$ under solar light irradiation. Moreover, these nanoparticles demonstrated antibacterial activities against $S$. aureus and $E$. coli. Therefore, it can be concluded that Simbang Darah extract provided a good yield of ferrite nanoparticles with desirable properties. Thus, it can be used to synthesize other materials in nanoscale.

\section{CRediT authorship contribution statement}

Rahmayeni: Conceptualization, Methodology, Validation, Writing Original Draft, Rike Febrialita: Investigation, Visualization, Yeni Stiadi: Writing - Original Draft, Yulia Eka Putri: Visualization, Validation, Nofrijon Sofyan: Writing - Review \& Editing, Zulhadjri: Writing - Review \& Editing.

\section{Declaration of Competing Interest}

The authors declare that they have no known competing financial interests or personal relationships that could have appeared to influence the work reported in this paper.

\section{Acknowledgment}

This work was funded by DRPM, Kementerian Pendidikan dan Kebudayaan of the Republic of Indonesia under Penelitian Dasar Kompetitif [grant contract number: T/26/UN.16.17/PT.01.03/AMD/PDMaterial Maju/2020, 10 Maret 2020].

\section{References}

[1] R. Rameshbabu, R. Ramesh, S. Kanagesan, A. Karthigeyan, S. Ponnusamy, Synthesis of superparamagnetic $\mathrm{ZnFe}_{2} \mathrm{O}_{4}$ nanoparticle by surfactant-assisted hydrothermal method, J. Mater. Sci. Mater. Electron. 24 (2013) 4279-4283, https://doi.org/10.1007/s10854-013-1397-6.

[2] V. Seetha Rama Raju, Synthesis of non-stoichiometric zinc ferrite for electromagnetic wave absorber applications, Mater. Sci. Eng. B Solid-State Mater. Adv. Technol. 224 (2017) 88-92, https://doi.org/10.1016/j.mseb.2017.07.012.

[3] S.M. Hoque, M.S. Hossain, S. Choudhury, S. Akhter, F. Hyder, Synthesis and characterization of $\mathrm{ZnFe}_{2} \mathrm{O}_{4}$ nanoparticles and its biomedical applications, Mater. Lett. 162 (2016) 60-63, https://doi.org/10.1016/j.matlet.2015.09.066.
[4] F. Martinez-Julian, A. Guerrero, M. Haro, J. Bisquert, D. Bresser, E. Paillard, S. Passerini, G. Garcia-Belmonte, Probing lithiation kinetics of carbon-coated $\mathrm{ZnFe}_{2} \mathrm{O}_{4}$ nanoparticle battery anodes, J. Phys. Chem. C 118 (2014) 6069-6076, https://doi.org/10.1021/jp412641v.

[5] K. Wu, J. Li, C. Zhang, Zinc ferrite based gas sensors: a review, Ceram. Int. 45 (2019) 11143-11157, https://doi.org/10.1016/j.ceramint.2019.03.086.

[6] S.V. Bangale, Nanostructured $\mathrm{ZnCo}_{2} \mathrm{O}_{4}$ thick film as an ethanol sensor, Int. J. Smart Sens. Intell. Syst. 7 (2014) 178-195, https://doi.org/10.21307/ijssis-2017-651.

[7] S.O. Aisida, P.A. Akpa, I. Ahmad, M. Maaza, F.I. Ezema, Influence of PVA, PVP and PEG doping on the optical, structural, morphological and magnetic properties of zinc ferrite nanoparticles produced by thermal method, Phys. B Condens. Matter 571 (2019) 130-136, https://doi.org/10.1016/j.physb.2019.07.001.

[8] M. Madhukara Naik, H.S. Bhojya Naik, G. Nagaraju, M. Vinuth, K. Vinu, R. Viswanath, Green synthesis of zinc doped cobalt ferrite nanoparticles: structural, optical, photocatalytic and antibacterial studies, Nano-Struct. Nano-Objects 19 (2019), 100322, https://doi.org/10.1016/j.nanoso.2019.100322.

[9] A. Behera, D. Kandi, S.M. Majhi, S. Martha, K. Parida, Facile synthesis of $\mathrm{ZnFe}_{2} \mathrm{O}_{4}$ photocatalysts for decolourization of organic dyes under solar irradiation, Beilstein J. Nanotechnol. 9 (2018) 436-446, https://doi.org/10.3762/bjnano.9.42.

[10] N.B. Singh Rachna, A. Agarwal, Preparation, characterization, properties and applications of nano zinc ferrite, Mater. Today Proc. 5 (2018) 9148-9155, https:// doi.org/10.1016/j.matpr.2017.10.035.

[11] N.G. Yadav, L.S. Chaudhary, P.A. Sakhare, T.D. Dongale, P.S. Patil, A.D. Sheikh, Impact of collected sunlight on $\mathrm{ZnFe}_{2} \mathrm{O}_{4}$ nanoparticles for photocatalytic application, J. Colloid Interface Sci. 527 (2018) 289-297, https://doi.org/ 10.1016/j.jcis.2018.05.051.

[12] H. Yang, X. Bai, P. Hao, J. Tian, Y. Bo, X. Wang, H. Liu, A simple gas sensor based on zinc ferrite hollow spheres: highly sensitivity, excellent selectivity and longterm stability, Sens. Actuators B Chem. 280 (2019) 34-40, https://doi.org/ 10.1016/j.snb. 2018.10.056.

[13] W. Shen, L. Zhang, B. Zhao, Y. Du, X. Zhou, Growth mechanism of octahedral like nickel ferrite crystals prepared by modified hydrothermal method and morphology dependent magnetic performance, Ceram. Int. 44 (2018) 9809-9815, https://doi. org/10.1016/j.ceramint.2018.02.219.

[14] S.B. Patil, H.S. Bhojya Naik, G. Nagaraju, R. Viswanath, S.K. Rashmi, M. Vijay Kumar, Sugarcane juice mediated eco-friendly synthesis of visible light active zinc ferrite nanoparticles: application to degradation of mixed dyes and antibacterial activities, Mater. Chem. Phys. 212 (2018) 351-362, https://doi.org/ 10.1016/j.matchemphys.2018.03.038.

[15] D.O. Okoroh, J. Ozuomba, S.O. Aisida, P.U. Asogwa, Thermal treated synthesis and characterization of polyethylene glycol (PEG) mediated zinc ferrite nanoparticles, Surf. Interfaces 16 (2019) 127-131, https://doi.org/10.1016/j.surfin.2019.05.004.

[16] S. Mandal, S. Natarajan, A. Tamilselvi, S. Mayadevi, Photocatalytic and antimicrobial activities of zinc ferrite nanoparticles synthesized through soft chemical route: a magnetically recyclable catalyst for water/wastewater treatment, J. Environ. Chem. Eng. 4 (2016) 2706-2712, https://doi.org/10.1016/j jece. 2016.05.020.

[17] M. Sriramulu, D. Shukla, S. Sumathi, Aegle marmelos leaves extract mediated synthesis of zinc ferrite: antibacterial activity and drug delivery, Mater. Res. Express 5 (2018) 1-9, https://doi.org/10.1088/2053-1591/aadd88.

[18] P. Laokul, V. Amornkitbamrung, S. Seraphin, S. Maensiri, Characterization and magnetic properties of nanocrystalline $\mathrm{CuFe}_{2} \mathrm{O}_{4}, \mathrm{NiFe}_{2} \mathrm{O}_{4}, \mathrm{ZnFe}_{2} \mathrm{O}_{4}$ powders prepared by the Aloe vera extract solution, Curr. Appl. Phys. 11 (2011) 101-108, https://doi.org/10.1016/j.cap.2010.06.027.

[19] K. Kombaiah, J.J. Vijaya, L.J. Kennedy, M. Bououdina, K. Kaviyarasu, R. J. Ramalingam, M.A. Munusamy, A. AlArfaj, Effect of $\mathrm{Cd}^{2+}$ concentration on $\mathrm{ZnFe}_{2} \mathrm{O}_{4}$ nanoparticles on the structural, optical and magnetic properties, Optik 135 (2017) 190-199, https://doi.org/10.1016/j.ijleo.2017.01.066.

[20] N. Matinise, K. Kaviyarasu, N. Mongwaketsi, S. Khamlich, L. Kotsedi, N. Mayedwa, $\mathrm{M}$. Maaza, Green synthesis of novel zinc iron oxide $\left(\mathrm{ZnFe}_{2} \mathrm{O}_{4}\right)$ nanocomposite via Moringa oleifera natural extract for electrochemical applications, Appl. Surf. Sci. 446 (2018) 66-73, https://doi.org/10.1016/j.apsusc.2018.02.187.

[21] M. Madhukara Naik, H.S. Bhojya Naik, G. Nagaraju, M. Vinuth, H. Raja Naika, $\mathrm{K}$. Vinu, Green synthesis of zinc ferrite nanoparticles in Limonia acidissima juice: characterization and their application as photocatalytic and antibacterial activities, Microchem. J. 146 (2019) 1227-1235, https://doi.org/10.1016/j. microc.2019.02.059.

[22] S.N. Ijioma, K.K. Igwe, O.N. Nwakudu, A.J. Madubuike, N.K. Achi, Preliminary evaluation of phytochemicals in Iresine herbistii ethanol leaf extract using gas chromatography-mass spectrometry analysis, J. Environ. Life Sci. 2 (2017) 21-28.

[23] C. Nencini, F. Cavallo, G. Bruni, A. Capasso, V. De Feo, L. De Martino, G. Giorgi, L. Micheli, Affinity of Iresine herbstii and Brugmansia arborea extracts on different cerebral receptors, J. Ethnopharmacol. 105 (2006) 352-357, https://doi.org/ 10.1016/j.jep.2005.11.022.

[24] Y. Cai, M. Sun, H. Corke, Identification and distribution of simple and acylated betacyanins in the Amaranthaceae, J. Agric. Food Chem. 49 (2001) 1971-1978, https://doi.org/10.1021/jf000963h.

[25] M. Valentová, R. Marek, E. Švajdlenka, R. Kubínová, V. Suchý, A new isoflavanone from Iresine herbstii, Fitoterapia 82 (2011) 272-275, https://doi.org/10.1016/j. fitote.2010.10.010.

[26] E. Walger, N. Marlin, F. Molton, G. Mortha, Study of the direct red 81 dye/copper (II)-phenanthroline system, Molecules 23 (2018) 1-23, https://doi.org/10.3390/ molecules23020242.

[27] S. Khamparia, D. Jaspal, Adsorptive removal of Direct Red 81 dye from aqueous solution onto Argemone mexicana, Sustain. Environ. Res. 26 (2016) 117-123, https://doi.org/10.1016/j.serj.2016.04.002. 
[28] Rahmayeni, A Alfina, Y. Stiadi, H.J. Lee, Zulhadjri, Green synthesis and characterization of $\mathrm{ZnO}-\mathrm{CoFe} 2 \mathrm{O} 4$ semiconductor photocatalysts prepared using rambutan (Nephelium lappaceum L.) peel extract, Mater. Res. 22 (2019) 2-11, https://doi.org/10.1590/1980-5373-MR-2019-0228.

[29] B.A. Hunter, Rietica - A Visual Rietveld Program, Australian Nuclear Science and Technology Organisation, Australia, 2000.

[30] R. Rahmayeni, Y. Oktavia, Y. Stiadi, S. Arief, Z. Zulhadjri, Spinel ferrite of $\mathrm{MnFe}_{2} \mathrm{O}_{4}$ synthesized in Piper betle Linn extract media and its application as photocatalysts and antibacterial, J. Dispers. Sci. Technol. 42 (2021) 465-474, https://doi.org/ 10.1080/01932691.2020.1721011.

[31] K. Ashwini, H. Rajanaika, K.S. Anantharaju, H. Nagabhushanad, P. Adinarayana Reddy, K. Shetty, K.R. Vishnu Mahesh, Synthesis and characterization of as-formed and calcined $\mathrm{MnFe}_{2} \mathrm{O}_{4}$ nanoparticles: a comparative study of their antibacterial activities, Mater. Today Proc. 4 (2017) 11902-11909, https://doi.org/10.1016/j. matpr.2017.09.110.

[32] N. Masunga, O.K. Mmelesi, K.K. Kefeni, B.B. Mamba, Recent advances in copper ferrite nanoparticles and nanocomposites synthesis, magnetic properties and application in water treatment: review, J. Environ. Chem. Eng. 7 (2019), 103179, https://doi.org/10.1016/j.jece.2019.103179.

[33] S. Rohilla Seema, Rietveld refinement and structural characterization of powder $\mathrm{ZnFe}_{2} \mathrm{O}_{4}$ synthesized through co-precipitation method, AIP Conf. Proc. 2142 (2019) 2-7, https://doi.org/10.1063/1.5122522.

[34] M.I. Din, S. Jabbar, J. Najeeb, R. Khalid, T. Ghaffar, M. Arshad, S.A. Khan, S. Ali, Green synthesis of zinc ferrite nanoparticles for photocatalysis of methylene blue, Int. J. Phytoremediat. 0 (2020) 1-8, https://doi.org/10.1080/ 15226514.2020 .1781783$.

[35] S.K. Rashmi, H.S. Bhojya Naik, H. Jayadevappa, R. Viswanath, S.B. Patil, M. Madhukara Naik, Solar light responsive Sm-Zn ferrite nanoparticle as efficient photocatalyst, Mater. Sci. Eng. B Solid-State Mater. Adv. Technol. 225 (2017) 86-97, https://doi.org/10.1016/j.mseb.2017.08.012.

[36] K. Laohhasurayotin, S. Pookboonmee, D. Viboonratanasri, Preparation of magnetic photocatalyst nanoparticles- $\mathrm{TiO}_{2} / \mathrm{SiO}_{2} / \mathrm{Mn}-\mathrm{Zn}$ ferrite and its photocatalytic activity influenced by silica interlayer, Mater. Res. Bull. 47 (2012) 1500-1507, https://doi.org/10.1016/j.materresbull.2012.02.030.

[37] Y. Cao, X. Lei, Q. Chen, C. Kang, W. Li, B. Liu, Enhanced photocatalytic degradation of tetracycline hydrochloride by novel porous hollow cube $\mathrm{ZnFe}_{2} \mathrm{O}_{4}$, J. Photochem. Photobiol. A Chem. 364 (2018) 794-800, https://doi.org/10.1016/ j.jphotochem.2018.07.023.
[38] R.S. Yadav, I. Kuřitka, J. Vilcakova, P. Urbánek, M. Machovsky, M. Masař, M. Holek, Structural, magnetic, optical, dielectric, electrical and modulus spectroscopic characteristics of $\mathrm{ZnFe}_{2} \mathrm{O}_{4}$ spinel ferrite nanoparticles synthesized via honey-mediated sol-gel combustion method, J. Phys. Chem. Solids 110 (2017) 87-99, https://doi.org/10.1016/j.jpcs.2017.05.029.

[39] K. Kombaiah, J.J. Vijaya, L.J. Kennedy, M. Bououdina, Studies on the microwaveassisted and conventional combustion synthesis of Hibiscus rosa-sinensis plant extract-based $\mathrm{ZnFe}_{2} \mathrm{O}_{4}$ nanoparticles and their optical and magnetic properties, Ceram. Int. 42 (2016) 2741-2749, https://doi.org/10.1016/j. ceramint.2015.11.003.

[40] L. Han, X. Zhou, L. Wan, Y. Deng, S. Zhan, Synthesis of $\mathrm{ZnFe}_{2} \mathrm{O}_{4}$ nanoplates by succinic acid-assisted hydrothermal route and their photocatalytic degradation of rhodamine B under visible light, J. Environ. Chem. Eng. 2 (2014) 123-130, https://doi.org/10.1016/j.jece.2013.11.031.

[41] G. Kenanakis, Z. Giannakoudakis, D. Vernardou, C. Savvakis, N. Katsarakis, Photocatalytic degradation of stearic acid by $\mathrm{ZnO}$ thin films and nanostructures deposited by different chemical routes, Catal. Today 151 (2010) 34-38, https:// doi.org/10.1016/j.cattod.2010.02.054.

[42] S. Meena, L. Renuka, K.S. Anantharaju, Y.S. Vidya, H.P. Nagaswarupa, S. C. Prashantha, H. Nagabhushana, Optical, electrochemical and photocatalytic properties of sunlight driven $\mathrm{Cu}$ doped manganese ferrite synthesized by solution combustion synthesis, Mater. Today Proc. 4 (2017) 11773-11781, https://doi.org/ 10.1016/j.matpr.2017.09.094.

[43] A. Arimi, L. Megatif, L.I. Granone, R. Dillert, D.W. Bahnemann, Visible-light photocatalytic activity of zinc ferrites, J. Photochem. Photobiol. A Chem. 366 (2018) 118-126, https://doi.org/10.1016/j.jphotochem.2018.03.014.

[44] J. Leichtweis, S. Silvestri, Y. Vieira, T.A. de Lima Burgo, E.L. Foletto, A novel tin ferrite/polymer composite use in photo-Fenton reactions, Int. J. Environ. Sci. Technol. (2020), https://doi.org/10.1007/s13762-020-02944-1.

[45] S. Sendhilnathan Hirthna, P.I. Rajan, T. Adinaveen, Synthesis and Characterization of $\mathrm{NiFe}_{2} \mathrm{O}_{4}$ nanoparticles for the enhancement of direct sunlight photocatalytic degradation of methyl orange, J. Supercond. Nov. Magn. 31 (2018) 3315-3322, https://doi.org/10.1007/s10948-018-4601-3.

[46] P. Chand Sukriti, V. Singh, D. Kumar, Rapid, visible-light-driven photocatalytic degradation using Ce-doped ZnO nanocatalysts, Vacuum 178 (2020), 109364, https://doi.org/10.1016/j.vacuum.2020.109364.

[47] C. Regmi, B. Joshi, S.K. Ray, G. Gyawali, R.P. Pandey, Understanding mechanism of photocatalytic microbial decontamination of environmental wastewater, Front. Chem. 6 (2018) 1-6, https://doi.org/10.3389/fchem.2018.00033. 